\title{
The Italian Opera Culture in Constantinople During the Nineteenth Century New Data and Some Ideological Issues
}

\author{
Vittorio Cattelan \\ (Università Ca' Foscari Venezia, Italia)
}

\begin{abstract}
Among the Turkish lyrics of Giuseppe Donizetti there are texts of singular modernity that exalt the Christians' and Muslims' brotherhood and accurately manifest the Tanzimat ideological value. Donizetti and other Italian composers took part in a metissage project also involving the Levantine community but above all the Constantinopolitan Armenians who managed the theatres and edited noteworthy translations of dramma per musica. The Italian composers, moreover, in writing Ottoman lyrics with Latin letters, apparently only to simplify the singer's reading, actually paved the way to the literacy process of modern Turkey. This essay aims to re-evaluate Italian opera's role in the Westernist aspiration context of 19th century Turkey.
\end{abstract}

Summary 1 Introduction. - 2 The Role of Donizetti Pasha during the Tanzimat. - 3 "Rimembranze del Bosforo". Angelo Mariani's Three Year Stay in Constantinople. - 4 Constantinopolitan Developments in Other Italian Composers. - 5 First Conclusions and New Perspectives of Research: the Sacred Metastasian Dramas Translated by Hovannes Yeremian

Keywords Constantinople. Tanzimat. Italian Opera. Multi-confessionalism. Armenian-Turkish.

\section{Introduction}

The facts I will try to describe and analyse in this essay concern, I believe, that meaning of culture suggested by the preliminary topics of the seminar Inerzia e Solerzia del testo. Genesi, Mezzi, Esiti dell'Agire Testuale (organised by PhD students of the Department of Asian and North African Studies) $)^{1}$ through these words of Gianfranco Marrone:

la cultura è un intreccio di testi e la società è il luogo dei flussi discorsivi delle diverse realtà testuali e culturali. (Marrone 2001, xxviii)

culture is a weave of texts and society is the venue of streaming conversation in the different cultural and textual realities (Transl. by the Author)

1 Università Ca' Foscari Venezia, 5-6 December 2017. 
I believe I can associate this notion of culture to a place in which "a weave of texts" is at work: this place is Constantinople. As it is well known, this metropolis in the early nineteenth century was already pervaded by a strong multiethnic, multicultural and multireligious component. By a specific and necessary material approach of history's sources, in this present essay (born from the proceedings of the above quoted seminar) I will deal with a relevant factor of cultural encounter that, starting from the first two decades of the nineteenth century, acts on this polyhedric reality. I would like to call this factor 'opera', or else the main product of the Italian musical tradition, but considered in its wide meaning: vocal and instrumental styles, of course the theatrical sphere, chamber or sacred music, and, last but not least, military music (which plays an important role in melodramma during the early nineteenth century). The concept of opera I am referring to is a plural and a social project in its productive system (represented by composers, librettists, singers, scenographers, translators, impresarios and publishers) eagerly desired and allowed by the new ideological policy of the sultanate, both in its relations with the West and with the minorities, in particular the Armenians.

\section{The Role of Donizetti Pasha during the Tanzimat}

Following the unsuccessful Italian uprisings of 1821, many Italians decided to move to Constantinople and with their own competencies and technocracies actively contributed in heading up the modernisation attempt of the Ottoman empire known as Tanzimat (1839-1876). The first radical and unavoidable provision in this re-organisation process was made in 1826 by the sultan Mahmud II (1789-1839) with the abolition of the Janissary order, whose members had maintained for centuries military power but at that time represented an obstacle to the empire's reform. ${ }^{2}$ It necessarily followed a new organisation of the army carried out thanks to the adoption of Western instructors and Westernised Ottoman officials, amongst whom stand out the Italian refugee Giovanni Timoteo Calosso (Turin 1789-Constantinople 1859) who achieved the elevated rank of chief of the Ottoman cavalry, receiving also the title of $b e y^{3}$ conferred upon him by Sultan Mahmud II. (De Leone 1967, 41-57; Türk 2007)

2 One of the cornerstones of the Tanzimat was the guarantees for life, honour and property equally granted before the law to all the subjects whatever their religions. For further studies on Tanzimat period see Costanza (2010) and the fundamental studies of Zürcher (1995; 52-79). For an extensive view on the socio-cultural transformations during the Tanzimat and the relationships between the religious communities see Braude, Lewis 1982.

3 The Turkish title bey was a noble title for chieftain, traditionally applied to the leaders or rulers of various sized areas in the Ottoman Empire but the term later came to use to indicate a financial or military administrator of a district such as Bey of Tunis. Finally the term became a simple appellative of respectable man. Gabrieli $(1966,139-142)$ Redhouse $(1968,164)$. 
As Calosso (1857) himself remembers in his Mémoires d'un vieux soldat, he suggested to the sultan the idea of introducing an Italian musician to teach Western music to the newly modernised band following the replacement of the music of the mehter" 'Ottoman band' traditionally combined with the Janissary military order. So thanks to the mediation of Vincenzo Groppallo, first minister of the Sardinian Delegation, the composer Giuseppe Donizetti was appointed, a choice which may have been influenced by a previous shared commitment with Calosso, as they both fought for the Savoy and Napoleonic army. In autumn 1828, following the sultan's invitation, Giuseppe Donizetti (Bergamo 1788-Constantinople 1856), the brother of the famous opera composer, arrived in Constantinople where he carried out his duty as music instructor until his death achieving the title of pasha, the highest rank of the Ottoman military hierarchy. ${ }^{5}$ Giuseppe Donizetti was welcomed into the sultan's palace and received the great benevolence of Mahmud II: the sultan, in fact, was himself a musician and even a skilled composer. It is known that Mahmud II inherited from his uncle Selim III, sultan from 1789 to 1808, both the reformist ideology and love for the music. ${ }^{6}$ Mahmud II was the author of a repertoire of thirty compositions, amongst which a dīvān, ${ }^{7}$ twenty-five şarkı 'love songs' and a tāvşānca 'dance of the rabbit' (music for a folk, maybe seductive, dance). Whereas as a member of the religious confraternity mevlievyye Mahmud II dedicated himself to the playing of the ney 'end-blown flute' typical of Ottoman classical music. ${ }^{8}$ Alongside to this classical, elite tradition, Otto-

4 In musicology this term indicates the band as a whole but the renowned dictionary by the Capuchin father Angelico da Smirne $(1955,594)$ provides the meaning of "single musician" of the Janissary band.

5 Giuseppe's intention to accept the role of music teacher offered by the sultan was initially criticised by his brother Gaetano, as witnessed by Gaetano's letter to his father Andrea dated 5 December 1827, in which he records his disagreement over the position taken by his brother and his hope to dissuade him not to make such an uncommon and risky choice at that time. For the details of the letter see Fornoni 2010, 142-3; Zavadini 1948.

6 Sultan Mahmud II received the appellative of Mahmūd 'Adlī, with the meaning of 'Mahmud the Fair' for his dedication to recovering the empire's social justice. According to legend he was son of Aimée de Rivery, cousin of Giuseppina de Beauharnais, captured by barbarian pirates and sold as a concubine to Sultan Abdülhamid I's (1774-1789) harem. Hence she would become the guiding principle for the son's French political line. See Pedani 2006, 109.

7 This term means the collection of poems of an author arranged alphabetically. Costanza $(2010,400)$ however use divan as a musical form what I think it is improbable. The same lyric entitled Ebrulerinin zahmı nihandır çiğerimde arranged by Dede Efendi is indicated in Üngör $(1981,138)$ as şarkı.

8 Ottoman classic music developed mainly around the Enderûn, i.e. the music school of the Court, the palaces of the musicophile elite and the sufi tekke, namely of confraternities mevleviyye and bektaşhiyye. Above all vocal Ottoman music traditionally accompanies a solo singer with a small instrumental ensemble. It has a large and varied system of modes 
man music was expressed through a plurality of traditions and reflected the vast and heterogeneous mosaic of the peoples who constituted the Ottoman Empire. During Donizetti's sojourn, the makam classical, Art music tradition, was represented by the famous Hammamizade İsmail Dede Efendi (1778-1846) and his disciple Hacı Arif Bey (1831-1885) whom Donizetti had met and with whom he had the opportunity to exchange musical teachings. Giuseppe's first occupation in Constantinople was to study the previous attempts at Ottoman music transcriptions. In particular he made use of the hamparsum notation which came from the name of the Armenian musician Hamparsum Limonciyan (1768-1839). ${ }^{9}$ He wished to plough through the teaching of Western music's notation to his pupils and at the same time approach the rich and composite Ottoman music sphere blending some examples of Janissary, classical and folk music into his compositions.

The role played by Donizetti in Constantinople is not restricted to his compositional activities, or his being music teacher (to the imperial band and harem) but is also proved by his important contribution to the knowledge of Turkish music in the West. Moreover Giuseppe brought to the Ottoman court's attention musicians such as Rossini, Verdi, Liszt and his own brother Gaetano, and contributed to the launching of the first operatic performances. ${ }^{\mathbf{1 0}}$

I have mentioned in the introduction of this essay the intimate relationship between opera and military Western music during the earliest nineteenth century, because of the innumerable "operatic representations" of military march in the opera of that period. For these reasons it is possible to speak of mutual influence between opera and the music of the military bands; however Donizetti and after him, as we will see, even other Italian

or scales known as makam, and various genres, including the spiritual, improvised (gazel, kaside, durak, respectively 'improvised solo singing, religious poem set in music, 21 beat rhythmic pattern') and fasil music in 'suite' form. See Feldman 1996; Costanza 2010. The classical makam was canonised and regulated directly by the sultan's court. For a complete list of Mahmud II's compositions, see Costanza 2010, 400. I have retraced and translated Mahmud II's lyrics and I will include them in my PhD dissertation.

9 Among the other previous attempts at Ottoman music transcriptions it is worth remembering those in Western staff notation from right to left made by the Polish Wojciech Bobowski (1610-1675), in what was called Mecmû'a-yi Saz ü Söz, as well as in his collection of psalms known as Mezmurlar, the transcriptions in Ottoman alphabetical notations made by the Moldavian voivoda Dimitri Cantemir (1673-1723), the examples in Western staff notation appended at the end of bailo Giambattista Donado (1627-1699) Della Letteratura de' Turchi (1688) which also includes some singular examples of Turkish lyrics written with latin letters and syllabified under the score and, one century after, at the end of the Letteratura turchesca by Giambattista Toderini (1728-1799). See Behar 2013; Toderini 1787; De Zorzi 2010, 33-5.

10 Gaetano Donizetti composed in 1841 the Gran marcia Militare Imperiale dedicated to Sultan Adbdülmecid. Liszt, during his six-week stay in Istanbul in 1847 composed a series of pianistic variations on the theme of the Donizetti's Mecidiye. Rossini composed two marches dedicated to the sultan and, as written in his letter dated 7 May 1852, he left the choice of which one to present to the sultan to Donizetti. See Araci (2006, 71). About the Donizetti's operatic involvement see also the witness of Gerard de Nerval $(1997,424-7)$. 
masters in Constantinople combine this hybrid musical tradition (opera and military music) with components of the Ottoman Art music tradition. In certain way they give back also some echoes derived from the so called current of style alla turca in vogue in the classical Western music (mainly in Vienna) since the seventeenth century. ${ }^{\mathbf{1 1}}$

The spread of operatic culture was, according to Spinetti, a phenomenon closely related to the re-organising process established in the Ottoman capital: it was certainly supported by an elite, diplomatic and Levantine society but it found acceptance also by a larger amount of non-Muslim minorities. For instance the Ottoman review Ceride-i Havadis notes that the Turkish libretto of Donizetti's Belisario was available for the low price of six kuruş 'cent', ${ }^{12}$ to capture people attention. ${ }^{13}$ The music of Donizetti Pasha and that of the great Italian opera composers was increasingly listened to people not just in the serail, in surroundings of the Topkapı Palace, in the Theatre of Pera situated in the European district but also in the living rooms of the wealthy Turkish and Armenian amiras and en plein air along the streets, through the numerous parades recounted by many foreign writers such as Hans Christian Andersen, Frederich Tietz, Gerard de Nerval, Adolphus Slade, Charles MacFarlane, Alphonse de Lamartine and the Princess Caterina Trivulzio di Belgiojoso, ${ }^{14}$ most of them quoted by Emre Aracı. ${ }^{15}$

11 See among others the recent study by Claudio Toscani (2010, 79-99). It is noteworthy that Leyla Saz in her memoirs of harem life remembers that some typical instruments of the disbanded Janissary corps, mainly percussion instruments such as the "Turkish crescent", continued to be played by the "Western fanfare" of the harem in the "Donizetti era" and thereafter. See Woodard 2011, 2-3. This fact is also confirmed by a same Donizetti's score in which you can see the employments of traditional Turkish instruments, i.e. the davul, a folk percussion instrument typical of the mehter and popular in all the country. See Giuseppe Donizetti I-Nc, MS. 63762. In the archival collection of Donizetti in Naples Conservatory are preserved pieces of alla turca of Antonio Salieri, one of the composers most involved in this Western classical style.

12 Silver coin in use during Ottoman period the name of which is now still used in Turkey to indicate a subunit of lira.

13 The review bears the date of 30 April 1842, and it is often quoted by the scholars see Turan; Ayşeoğlu $(2007 ; 12)$ and Mestyan $(2011 ; 342)$. The latter quotes as source Sevengil (1959, 66-71) stating that the author of the Turkish libretto of Belisaro is Heyrullah Efendi which actually is not demonstrated by an attentive reading of this book. There may be confusion from the fact that Hayrullah Efendi is considered the author of the first Ottoman Turkish libretto in four acts entitled İbrahim Paşa ile İbrahim Gülşenì'in hikāyesi 'Story of Ibrahim Pasha and Ibrahim Gülşenī' composed in 1844, the same year he achieved his graduation.

14 She was a writer and journalist who came to Constantinople after her participation in the first Italian Risorgimento phase. She wrote several essays among which worth remembering is her Souvenir dans l'exile (1946; 2001, 281) In Constantinople she looked for employment as singer and music teacher and as she testified she gave support occasionally to Donizetti in teaching Western music to the royal pupils at the Imperial music school situated in Üsküdar. De Leone 1967, 67-186.

15 Aracı $(2006,62,95,157 ; 2010,65)$. Nerval reports his attendance of the opera Buondemonte (Maria Stuarda) directed by Giuseppe Donizetti, who, according to the writer, was also 
As Namık Sinan Turan and Ayşegül Komşuoğlu refer in their essays, the perception of opera in Turkey, permeated around the 1830s even among muslims, surprisingly reveals its incorporation in some religious ceremonies (Turan, Ayşeoğlu 2007, 12). Alphonse de Lamartine remembers that, during the Cumasalamlığı 'Friday's prayers', attended by the sultan himself, the imperial band played a repertory ranging from Mozart to Rossini. ${ }^{16}$ These were not isolated incidents limited to Constantinople: Adam Mestyan says in his recent study on military music in Egypt, Western music was appreciated during Muslim religious ceremonies (Mestyan 2013, 647) and it had similar wide appeal also in all the Mediterranean countries, each of them with their own leading actors (Spinetti 2010, XII-XIV).

According to Federico Spinetti's Introduction of the volume dedicated to Giuseppe Donizetti in 2010, the role of the Italian master was both that of opening the way to several Turkish musicians, composers and orchestra conductors, and that of "significantly influencing traditional Turkish music" starting a metissage process continued in the next wave of European masters to the Ottoman capital. However Donizetti also promoted a new kind of poetry that could represent the ideological development of the new course of the sultanate.

Although almost completely unpublished, of great interest are Donizetti's lyrics sung in Turkish, but written in Latin phonetics to simplify the singer's reading, whose corpus I retraced searching within the library of the Conservatorio San Pietro a Majella of Naples, the Civic Library Angelo Mai and the Museo Donizettiano of Bergamo, and the archive of the Topkapı Palace of Istanbul. I have drawn up a translation of this corpus, composed mostly of hymns, such as were in vogue in the main European countries during that period: Donizetti's compositions presented patriotic features and some were even utilised as a national anthem. ${ }^{17}$ The following are the titles of the compositions: Cansone

appointed by his brother to collect Greek and Wallachian arias for his operas. Nerval (1997, 424-7). Less known among the scholars is the testimony of Tietz (1838, 37-47), who recounts he was invited as a guest for a dinner by a rich Turkish renegade, on which occasion a band composed of "Turkish, Gipsy and Jewish" musicians played pieces of Ottoman music and then also a popular venetian barcarola. See also "Della musica nella Turchia" 1852, 140-1.

16 As Alphonse de Lamartine $(1841,266)$ writes in June 1833 in his Voyage en Orient (1832-1833).

17 Among Giuseppe's first compositions there were the two instrumental marches: the Mahmudiye, dedicated to Sultan Mahmud II and Mecediye, dedicated instead to his successor Abdülmecid. These were the first hymns officially accepted in the Ottoman empire. See Aracı 2007, 276. 
mussulmana, ${ }^{\mathbf{1 8}}$ Inno di Sua Maestà Imperiale il Sultano Abdül Medgid, ${ }^{19}$ Canzone Popolare Turca, ${ }^{20}$ Per il ritorno del sultano Abdulmegid parole di Hairy Efendi, ${ }^{21}$ Inno di S.A.I. il Sultano Abdulmegid, ${ }^{22}$ Inno di S.A.I. Valide Sultana ${ }^{\mathbf{2 3}}$ and Silistria also with Italian words by the poet-patriot Achille Tondi (San Severo 1826-Costantinopoli ca. 1860), the most relevant literary figure to whom all the Italian musicians of the Ottoman capital addressed their requests for poetry and translations. ${ }^{24}$ The contents of these songs are mainly in praise of lawfulness and modernity, and celebrate the love of the homeland too, but, for example in the Canzone Popolare Turca, besides these themes, calls to harmonious coexistence between Christians and Muslims, and to behave with humanity appear. Let me quote a salient tercet of this song:

Musulmanler ylé christianler
sevichoup ulfat itmeli-dirler
chan insanieté alich-sounler

Christians and Muslims

have to love and care for each other and humanity must be familiar to the peoples (transl. by the Author)

In line with the Tanzimat's ideological values, Donizetti's lyrics aimed to mitigate the religious conflicts of peoples belonging to the sultanate and avoid their demand for independence (supported also by European powers). However it seems to me also the music's combination with the Ottoman lyrics transliterated with Latin letters, adopted by Donizetti, apparently with the sole purpose of simplifying the singer's reading,

18 I-Nc. Raccolta di diversi Pezzi di Musica composti da Giuseppe Donizetti per musica militare e ridotti per piano forte dall'autore. IT-NA0059 20.7.3@10.

19 I-Nc. Inno di Sua Maestà Imperiale il Sultano Abdül Medgid. Fondo Giuseppe Donizetti, 63653.

20 I-Nc. Canzone popolare turca. Fondo Giuseppe Donizetti, 63761.

21 Napoli, I-Nc. Per il Ritorno del Sultano. Abdul Medgid. Parole di Hairy Efendi, 63649. As indicated in the title this lyric was not composed by the Italian composer therefore, and in accordance with Aracl (2006) and Spinetti (2010) we can deduce that, probably with the assistance of a poet-translator, Donizetti was the author of the other lyrics.

22 Donizetti (1846).

23 Donizetti (1846).

24 Donizetti (1854); for further informations about the poet Achille Tondi see Russi (2009).

25 I-Nc. Canzone popolare turca. Fondo Giuseppe Donizetti, 63761. 


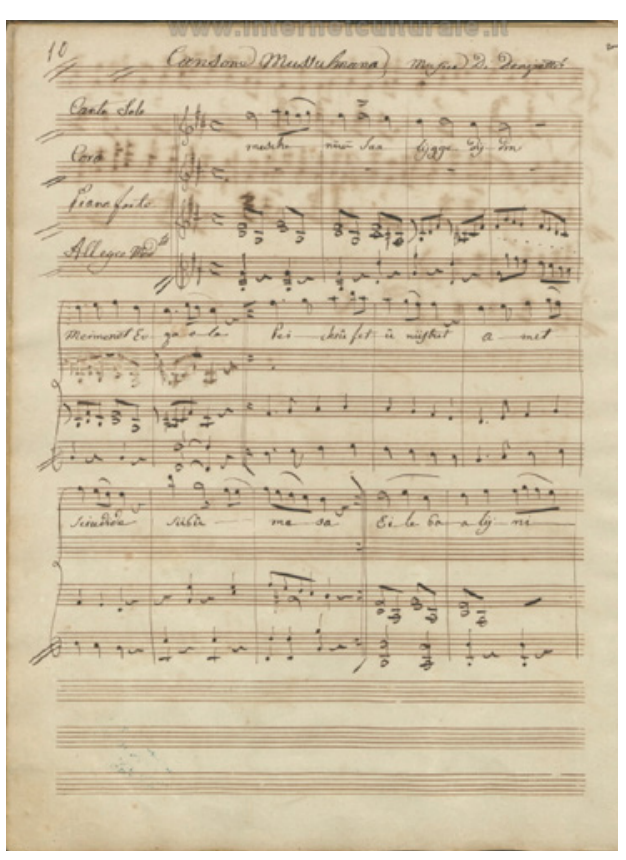

Figure 1. Giuseppe Donizetti, Cansone Mussulmana. Raccolta di diversi Pezzi di Musica composti da Giuseppe Donizetti per musica militare e ridotti per piano forte dall'autore, 1832. I-Nc, P. 20. IT-NA0059 20.7.3@10

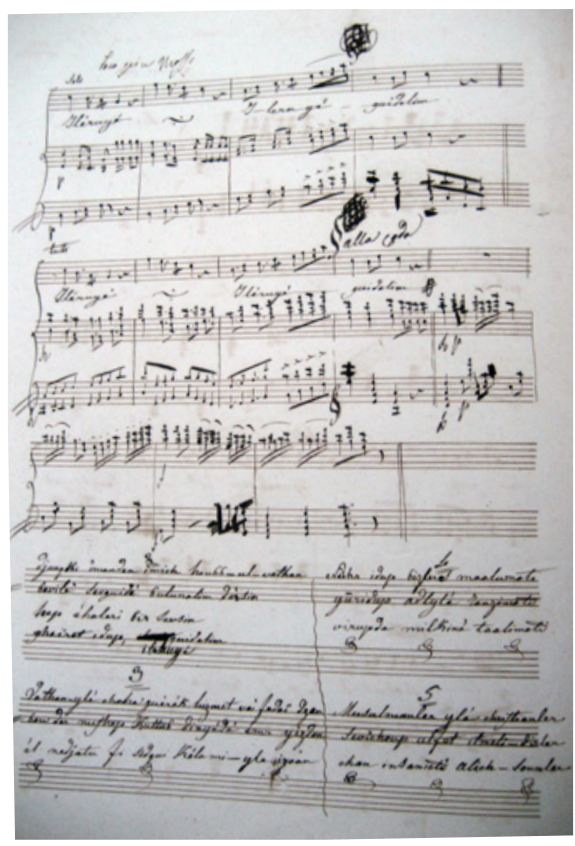

Figure 2. Giuseppe Donizetti, Canzone popolare turca, 1839 ca. P. 2, I-Nc, Fondo Giuseppe Donizetti, 6376.

represents instead another important component of cultural metissage. ${ }^{26}$ In some measure it shows clearly the spoiling of Ottoman music's oral traditions, ${ }^{27}$ but at the same time it became unquestionably a groundbreaking experimental use of the transcription and syllabification of spoken Turkish language with the Latin alphabetic letters. From a more general point of view, Murat Cankara sustains, in his recent article on

26 As it is known Ottoman Turkish was used by the Court, the diplomacy and the literati and it was written with Arabic-Persian letters however there are some exceptions of the use of Turkish in latin letters, employed by dragomans and above all by erudite-grammarian for didactic or lexicographic purposes since the sixteenth century which reveal interesting developments of the history of the Ottoman phonetic. Several studies on the so called Turkish literature in latin letters are been published by the Turkologists such as Bombaci 1948; Gallotta 1990; Rocchi 2013; Yağmur 2014.

27 It is well known the vocal text in Ottoman tradition is learnt by memory, not writing. 


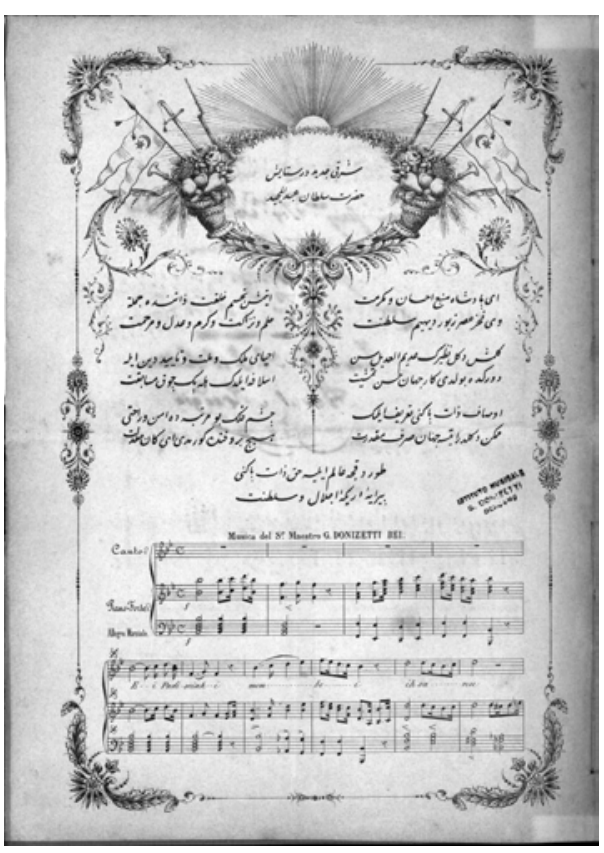

Figure 3. Giuseppe Donizetti, Inno di Sua Maestà Imperiale il Sultano Abdül Medgid, 1846. I-BGi, 3540

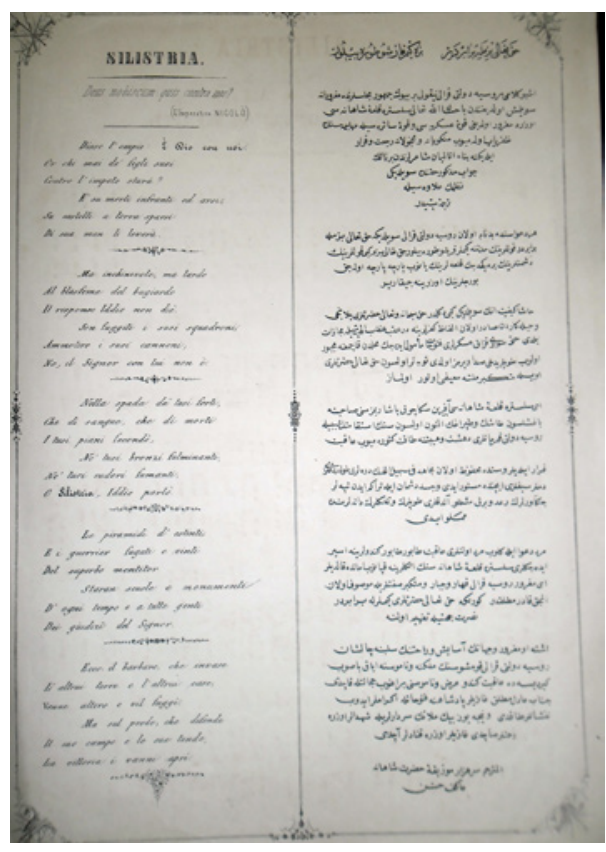

Figure 4 Giuseppe Donizetti, Silistria, 1854. P. 2, I-Nc, 63701

the question of the cross-cultural encounters in the Ottoman empire, that, from the 1860s, have occurred an important debate on the replacement of the Ottoman writing system with the Latin which gradually evolved, during the first quarter of the twentieth century, into a "war of scripts" (Cankara 2015, 6) between those who support the Latin alphabetical character, those who argue for a reform of the Arabic and even those who propose a convincing alternative with the Armenian script. The above-mentioned music technique of rhythmic-syllabic adaptation of the Turkish words in Latin letters, almost unknown in the Ottoman lyric tradition, opened the way, as we will try to see in this short essay, to similar works of other Italian composers, becoming a particular model of transcultural action. 


\section{3 "Rimembranze del Bosforo". Angelo Mariani's Three Year Stay in Constantinople}

The most noteworthy case of continuity in this work of Donizetti lies in the Inno Nazionale dedicated to Sultan Abdülmecid (1823-1861) by the musician Angelo Mariani (1821-1873) from Ravenna, sung in Turkish on 28 January 1849 and printed for the first time by the publisher Fredéric Brochtorff in Beyğolu, Constantinople. Significantly, this printed edition presents on the dust cover the tuğra 'imperial signature' of Sultan Abdülmecid, next in the following pages the poetic text in its original Ottoman form, then in the third sheet 'translated' into Italian by Achille Tondi, and finally the lyric score, for male chorus and orchestra, where, immediately under the vocal part, the words of the text appear in Italian and further below, as still happens today in the bilingual rhythmic versions, in Ottoman-Turkish written in Latin characters. As Mariani writes in his letter to Giovanni Ricordi of 25 April 1849:

le parole Turche vi sono scritte coi caratteri francesi, non potendolo fare altrimenti poiché la sillabazione Turca camina viceversa della nostra e non permette la separazione delle sillabe. ${ }^{28}$

The Turkish words are written with French characters. This could not be otherwise because Turkish syllabification is quite different to ours and does not permit the separation of the syllables. (Transl. by the Author)

As we will see in the music score which Ricordi would print, the Turkish words are also written in Latin characters with a clarification note to the singers: "Read the Turkish words with the Italian pronunciation" (Mariani 1849). The National Anthem of Mariani was a success that he immediately shared with the publisher Giovanni Ricordi in his 20 March 1849 letter, with the evident reason of communicating that it would be printed at the expense of the Grand Master, thus enticing Ricordi also to make a print in Milan (this would certainly happen):

Le faccio noto con tutto il piacere che sua Maestà il Gran Sultano mi ha onorato col regalarmi una ricca tabacchiera in brillanti munita di suo maggior sigillo del valore di cinque milla franchi, per aver io composto in Lingua Turca un Inno nazionale il quale venne a sua richiesta replicato in sua augusta presenza il giorno che onorò con la sua venuta il Teatro.

Di più ha Egli ordinato che sia stampata tutta la partitura ed adotato in

28 I-Mr, Fondo Corrispondenza, MS. PIV2_01a-013. I have chosen to maintain always the authentic orthography of Mariani which clearly reveal the way of speaking in use in his native region. 
tutto il suo regno. Appena sarà fatto sarà mio dovere il mandargliene una coppia accio Ella caro Signor Giovanni possa farne quel conto che più le agrada. Questo mio lavoro ebbe sorte fortunata anche presso il pubblico perché ne dimandano sempre la replica. ${ }^{29}$

I communicate to you with pleasure that his Majesty the Great Sultan honoured me with a rich snuffbox of diamonds, carrying his highest seal and worth five thousand francs, for having composed a national anthem in Turkish which was then repeated at his request in his august presence the day that he honoured the theatre with his coming. He also ordered that the whole score be printed and adapted throughout his kingdom. As soon as it is done, it will be my duty to send it to you, so you can use it as you please. This work of mine also had great fortune with the audience because they always ask for it to be again performed. (Trans. by the Author)

Following the instructions of Mariani, the succeeding year Ricordi provided a reprinting of the work which the musician welcomed with these words in his letters of 17 May $1850:^{30}$

Mi fa molto piacere che Ella abbia ristampato il mio Inno Turco colla traduzione in Italiano. Questa cosa farà molto piacere anche a sua Maestà perché ama assai questa composizione. Veramente non è gran cosa, ma chi ha sentito le preghiere dei Turchi, non potrà far di meno da non trovarci il genere suo. Ed eseguito a piena orchestra è di un effetto sicuro. Lultima sera della stagione teatrale si terminò colla replica di quello. Se Ella me ne manderà una copia in carta fina ed alquanto elegante io la farò presentare a Sua Maestà a suo nome per qualche sicuro mezzo, e sono certissimo che l'aggradirà molto ma molto. Così vedrà che il Chiarissimo Editore Giovanni Ricordi vuol pure con ciò offrile anch'egli il suo omaggio. ${ }^{31}$

I appreciate very much your reprinting my Turkish Hymn with the Italian translation. This will give great pleasure to His Majesty because he loves this composition a greatly. Actually it is nothing special, but whoever has listened to the prayers of the Turks will never fail to notice his genre. And performed with the full orchestra, its result is guaranteed. The last evening of the operatic season finished with an encore performance of it. If you send me a copy of some elegance on fine paper I will make a present of it to His Majesty in your name through some safe means and I am really very sure that he will appreciate it really very much. In this

29 I-Mr, Corrispondenza MS. PIV2_01a-11.

30 I-Mr, Corrispondenza MS. PIV2_01b-035.

31 I-Mr, Corrispondenza MS. PIV2_01b-035. 
manner he will see that the esteemed publisher Giovanni Ricordi also wants to offer his own present. (Transl. by the Author)

No less important than that of Donizetti is, in fact, the figure of Angelo Mariani on whom we must focus a little at this point. Born in Ravenna in 1821, much younger than Donizetti, Mariani arrived in Constantinople in 1848 to escape Austrian repression following the Revolution of 1848 when he had enlisted as a volunteer in the ranks of the Sardinian-Piedmontese army. Mariani was then a very talented violinist, already established as a conductor in some of Verdi's operas. ${ }^{32}$ He showed his willingness to put his art to the service of the national ideal and as a conductor, a concept very close to that of today in which a single person plays both the roles of 'maestro concertatore' and conductor. ${ }^{\mathbf{3}}$ Mariani arrived in Costantinopoli unwillingly and with a lot of prejudice towards the place, the life and culture in the Ottoman capital and he was subjected to the multicultural influence of the metropolis, proving himself ever more sensitive to the Turkishs' usual behaviour and civic-religious way of thinking. As he wrote in a letter of 12 October 1850:

intorno all'Inno Turco che Lei deve stampare mi fu raccomandato sopra a tutto che non vi siano figure sopra al frontespizio. Uccelli, alberi, aria tutto ciò che desidera l'artista, ma figure di uomini no perché la religione Turca non lo permette. Una copia bellissima per il Sultano altre tre di meno lusso per il primo pascà, qualche altra per i più piccoli pascà, ed altre per i ministri. ${ }^{34}$

On the subject of the Inno turco which you have to print, It was commended to me above all else that on the frontispiece there be no images. Birds, trees, air and everything that the artist wishes, but no human representation because their religion does not allow it. One really beautiful copy for the sultan and another three more in less luxury form for the first pasha, some other for the smaller pasha, and others for the ministers. (Transl. by the Author)

In his letter of 21 December 1850, Mariani wrote to the publisher to tell him also about the difficulties encountered by Achille Tondi in adapting the libretto of Verdi's Lombardi alla prima crociata so it could be accepted by a Muslim audience:

32 About the relationships between Verdi-Mariani see Walker 1964.

33 'Maestro concertatore' was generally the first violin of the orchestra who dictated the phrasing and the so called arcate of the whole bowed instruments.

34 I-Mr, Corrispondenza MS. PIV2_01b-045. 
ora si stanno provando i Lombardi alla Prima Crociata del M. Verdi. In quanto al libretto però non sono più i Lombardi di Solera perché non potendosi qui rappresentare a cagion dei Turchi quest'opera così come si trova col battesimo, coll'harem, colla presa D'Antochia, con quell'empie bende, con quegl'empi musulmani che ricorrono ad ogni tratto, l'impresa ha incaricato il poeta Tondi a ridurre il libretto in modo che non ne potesse venir offesa la suscettibilità politica e religiosa dei discendenti di Osmano. Io credo che avrà dovuto trasportare l'azione in altro luogo e ad altri tempi; in modo diverso io non saprei come si possa cavarne le mani. Ma essendo così ben veggo che per quanta abilità possa avere il riduttore non riussirà mai a non togliere a questa musica il tipo caratteristico che ella ha di quel fatto messo nella storia. Intanto staremo a vedere cosa n'uscirà. ${ }^{35}$

Now they are rehearsing the Lombardi alla prima crociata of Master Verdi. Talking of the libretto by the way, it is not anymore the Solera Lombardi because it might not be performed by reason of the treatment of the Turks. This opera as it is, with the baptism, with the harem, with the conquest of Antioch, with those unholy turbans, and with those unholy Muslims which occur in each part, the company charged the poet Tondi to adapt the libretto in the way so that it might not offend the political and religious susceptibility of Osman's descendants. I believe that he must have carried the action to another place and in other times; in a different way I would not know how one would do it. Being so, I well see that whatever skill the reducer may have, he will never be able to not take away from this music the characteristics that he has put into this history. Meanwhile, we will see what happens. (Transl. by the Author)

As the poet Achille Tondi wrote in his review in the Gazzetta Musicale dated 5 May 1850, which offers us an interesting portrait of Mariani within the Constantinopolitan milieu:

io seguo con tenera simpatia i passi di codesto giovane ingegno che, in materia d'arte, fa caro ed onorato il nome italiano all'europea barbarie di Costantinopoli (dove del resto i barbari non sono i Turchi). In tanta penuria di buoni ingegni, e mentre la musica cerca e non trova chi sappia farla risorgere alla primitiva sua altezza, Mariani potrebbe chiamarsi speranza dell'arte, se il suo soggiorno in questo deserto dell'intelligenza, il non consacrarsi a tutt'uomo a robusti studi ed a continuati esercizi, e l'essersi egli fatto un culto esclusivo per la maniera di Verdi, non nuocesse all'originalità delle sue proprie ispirazioni e non menomasse la 
certezza di que' risultati che potremmo diversamente ripromettercene. (Tondi 1850, 89-90)

I follow with affectionate sympathy the steps of this young talent who, in matters of art, makes precious and honoured the Italian name to the European barbarity of Constantinople (where after all the barbarians are not the Turks). In lack of good wits, and while the music seeks and does not find anyone who knows how to let it resurge to primitive height, Mariani could be called the hope of art, if his stay in this desert of intelligence, not to be consecrated to a man of robust studies and continued exercises, and having made himself an exclusive cult for the manner of Verdi, did not harm the originality of his own inspirations and did not undermine the certainty of those results that we could otherwise promise. (Transl. by the Author)

In Constantinople, Mariani developed this new conception of his orchestra conducting and he became the dominant spirit in an international atmosphere that was centred on the theatre of the Christian Sirian brothers Naum $^{36}$ of Pera. Here during the seasons 1848-1849 and 1850-1851 he led several operas of Verdi, Bellini, Meyerbeer, Rossini and Donizetti. Until November 1851 he still remained in Constantinople devoting himself mainly to the composition and teaching. The city life and the Turkish delight of Büyükdere would be the inspiring motive of the birth of some chamber romance albums entitled Rimembranze del Bosforo, (almost like a recurring image showing his attachment to the city) Una notte sul Bosforo for cello and piano, the scenic cantata Matilde or La Fidanzata del Guerriero, Il Canto dell'Esule with the words by Achille Tondi (Potito 1985, 20-23).

Mariani's mentor, in his almost three year stay in Constantinople, was the Russian ambassador Dimitri Sergejievic De Titov who accommodated him in verdant Büyükdere, the district populated by Greeks and Armenians in whose houses the Italian musician gave singing piano and composition lessons as well as doing Academies (concerts), delighting 'the lords', bourgeois and aristocrats of different nationalities as well as mainly religious Armenians who knew and required the execution of favourite pieces such as the Stabat Mater by Rossini or that by Pergolesi. Moving from neighbourhood to neighbourhood on horseback or along the banks of the Bospho-

36 The Naum brothers are also remembered as Armenians (Arditi 1896, 44) and their father was an Aleppian nobleman in the service of the Ottoman Porte. Michel Naum also served as a dragoman and later travelled in the same role with Lady Stanhope, finally settling in Constantinople. See Mestyan 2011, 110; Aracı 2010. As theatre producers, they were greatly involved in the cultural-artistic life of Constantinople, and were internationally renowned, as attested by the rich correspondence between Mariani and Ricordi. (Michael Naum travelled several times to Milan to arrange operatic staging with the publisher Ricordi, meet artists, buy scores, etc.). 
rus with a modern paddle steamer or with the most rustic and traditional caicco 'gulet', Mariani went to Pera every day to give lessons to the Armenian women's college of the nuns of the Immaculate Conception and had as students the Armenian Alexanian Adelaide Diran, a composer herself, the Turkish Madame Devlet, the daughters of Francesco Franchini, first dragoman of the Russian legation at the Sublime Porta. ${ }^{37}$ These meetings provide a first glance of his one-year experience in the broad spectrum of the Levantine city still studded with the conversations with the poet Achille Tondi, the composer Callisto Guatelli, and the impresario Naum brothers at the Greek café (smoking Cibuch, the 'Turkish tobacco pipe' and sipping lemonade), at receptions at the palace of the British Minister Stratford Canning (1786-1880), ${ }^{38}$ and at that of the Russian baron and diplomat Egorovic Staal (1822-1907) and at the house of the French banker Alléon where every evening music echoed along the banks of the Quai. These names and situations fill the pages of an unpublished manuscript, an autobiographical diary that Mariani kept in the year 1851 and now held in the Library Livio Simoni of the Museo Teatrale Alla Scala. ${ }^{39}$ It is a document of great historical and social interest that I was able to study and finally, only in recent days, reconstruct according to its original chronological arrangement, and fighting away through its state of total confusion. Except for Emre Aracl who refers a rough but not unrealistic dating of the diary, scholars generally do not deal with this source with the proper attention due to the very difficult comprehension of Mariani handwriting and rushed arrangement. ${ }^{40}$ This diary documents the meeting of cultures in the city under the aegis of a common passion for music beyond the national and religious boundaries, even though the latter are deeply felt. Another documentary source of Mariani's stay in Constantinople, which also allows us to know the economic profile of the operatic culture in the Ottoman capital, is the correspondence with the publisher Giovanni Ricordi, also unpublished, which includes

37 This is an Armenian Catholic female college run by the Sisters of the immaculate conception whose order was founded in 1846 by the archbishop Hassoun where besides the Catholic religion, were taught Armenian, French and Italian and a whole series of highquality artefacts were produced. See "Cose straniere" 1885, 245. As witnessed by Mariani's diary also music would be taught.

38 According to Zürcher 1995. Canning had a crucial role in the British support to the reforms (ambassador from 1851 to 1858). He was on close terms with many of the leading Ottoman reformers (Reşid Paşa, Fuat Efendi, Mehmet Emin Ali) he is generally considered a Russophobo but from the Mariani testimony we can understand that his political and cultural position is more in favour of a broad internationalist view.

39 I-Ms, Diario autobiografico di Angelo Mariani, (Dono M. ${ }^{\circ}$ Carlo Gatti) 1940, MS. 20494.

40 Araci 2010, 137. I have patiently transcribed the entire diary of Mariani's stay in Constantinople and finally I have managed to deduce that it runs from the 31 May to the 20 November 1851. I will include in my PhD dissertation an annotated transcription of this document. 
forty-four letters between October 1848 and December $1851 .^{41}$ Even the first letter dated 12 October 1848 reveals the intention of Mariani to suggest that Ricordi start a shop with books and musical items in general in Constantinople, together with Leopardo Moretti, copyist and prompter of the Teatro Naum from 1842, where 'Cavalier Donizetti' would assume the role of cashier. The letter details the list of points in the contract:

Art. $1^{\circ}$ Il signor Ricordi dovrà somministrare tutta quella musica che dal Moretti gli avrà ordinato.

Art. $2^{\text {do }}$ La musica invenduta dovrà rimanere a carico del Sig. Ricordi.

Art. $3^{\text {zo }}$ Il Moretti si obbliga di armare a proprie spese un magazzeno fabbricato in pietra con sue vetrine e pagarne il rispettivo affitto.

Art. $4^{\text {to }}$ Gli incassi veraño Rimessi nelle mani del Sig. Cavalier Donizetti o di altra persona nominata dal Signor Ricordi.

Art. $5^{\text {to }}$ Sarà tenuto un giornaliero registro della vendita.

Art. $6^{\text {to }}$ Tutte le commissioni particolari che riceverà il d ${ }^{\text {to }}$ Moretti saranno a Beneficio del Sig. Ricordi, e questi sarà tenuto di dare al Moretti il $10 \times 100 .{ }^{42}$

Art. $1^{\circ} \mathrm{Mr}$. Ricordi shall consign all the music that Mr. Moretti has ordered him to do.

Art. $2^{\circ}$ The unsold music shall remain the responsibility of Mr. Ricordi.

Art. $3^{\circ} \mathrm{Mr}$. Moretti undertakes to furnish at his own expense a warehouse made of stone with its display cabinets, and pay the respective rent.

Art. $4^{\circ}$ The earnings will be returned to the hands of Mr. Cavalier Donizetti or another person named by Mr. Ricordi.

Art. $5^{\circ}$ A daily register of sales will be held.

Art. $6^{\circ}$ All the special commissions received by the mentioned Moretti will be to the benefit of Mr. Ricordi, and he will be obliged to give Mr. Moretti $10 \times 100$. (Transl. by the Author)

The music store would be based in Beyoğlu, the district of Pera where most of the Europeans resided and would have to be built in stone and not in wood since the main danger was fire. The price of renting a stone shop would have been excessively high (equal to 150 francs a month), as the composer points out, but it would have been worth it given the lower risk of fire. With these arguments he asks for a discount on the cost of

41 The annotated edition of the entire correspondence between A. Mariani and G. Ricordi will be available with my $\mathrm{PhD}$ dissertation.

42 Mariani's letter, Constantinople 12 October 1848, I-Mr, Corrispondenza, MS. PIV2_01a-007. 
providing music which would be amply repaid by the greater safety of the building chosen for the shop:

la notte scorsa la passammo in strada perché ebbimo il foco in Galata Serai il quale distrusse più di cinquecento case, e questo si dice che sia stato dato apositamente, perché il governo non ama far case di legno, avendo proibito di fabbricare in simile modo. Molti individui della nostra compagnia che abitavano in quel quartiere hanno perduto la maggior parte della sua robba. A noi forestieri ci fanno senzo simili disgrazie, ma qui ci sono talmente avezzi che mentre la sua casa arde essi fumano una pipa di tabacco. ${ }^{\mathbf{4 3}}$

We spent last night in the street because we had the fire in Galata Serai which destroyed more than five hundred houses, and this is said to have been done on purpose, because the government does not like to make wooden houses, having forbidden building in such a way. Many people in our company who lived in that neighbourhood have lost most of their belongings. We foreigners are astonished, but here they are so used to this that while his house burns they smoke a pipe of tobacco. (Transl. by the Author)

Fortunately, the Naum Theatre where the company was performing did not suffer great damage because the building had already been rebuilt in stone some years before according to a first design by the architect Giuseppe Fossati, ${ }^{44}$ following a great fire that had broken out in 1846 and had completely destroyed it. The high cost of the rent continued to be the main obstacle to the opening of a store with its own building independent from that of the theatre, which in fact continued to be the headquarters of the Ricordi bookshop and to store a lot of music from the Milan house whose sale Mariani continued to take care of during his whole stay. Here I have just space to quote one more passage from the letter of 9 November 1850 in which besides reporting the success of Lucia di Lammermoor by Donizetti with a first-rate cast, Mariani also gives an account of the tragic event of the bloody anti-Christian 'revolution' in Aleppo that the army of the sultan could not stem and that was therefore the cause of a serious political and diplomatic crisis:

43 I-Mr, Corrispondenza, MS. PIV2_01a-007.

44 Actually Giuseppe Fossati gave up the design of the Naum Theatre which was took up by the English architect William James Smith who completed the building. Aracı (2010, 105-107) Dadyan (2017, 130). The architect Giuseppe Fossati (1822-1883), together with his older brother Gaspare Trajano (1809-1891), also an architect, designed a large number of public buildings, churches, embassies and private residences in Constantinople. Giuseppe in particular restored the basilica of S. Sofia. See And 2004, 49 note 13; Lacchia 1943; Lacchia 1939, 3-7; Palumbo Fossati Casa 2006. 
per l'ulteriore andamento posso dirle che lo spartito va sempre tanto bene quanto la prima sera, e che il Teatro è affollato di spettatori. La Signora Penco, e la Signora Lotti prime donne, il basso profondo Signor Mitrovich ed il Tenore Signor Prudenza riscuotono sempre grandi applausi. Martedì prossimo andremo in iscena colla Lucia, in cui canterà la Penco, Baggetti, Corsi, ed Alessandrini. Sabbato venturo gliene darò notizia. Adesso è scopo che le dica qualche cosa intorno alla presentazione del mio Inno al Gran Sultano. Sfortunatamente sono qui suceduti avvenimenti gravissimi che hanno messo sossopra la Corte, la diplomazia, e fanno traballare l'attual ministero. Una sanguinosissima rivoluzione in Aleppo, e si suppone anche nei luoghi circonvicini, ove han tagliato a pezzi molta parte della popolazione franca, saccheggiate le case e incendiato il quartiere ove quella abitava. Nel medesimo tempo qui è saltata in aria la Nave amiraglia, souvra alla quale fra un'altra mezz'ora doveva recarsi il Sultano. Era il più gran legno della marina Turca a tre ponti e mezzo con cento sessanta cannoni. Senza sapere il come prese fuoco la santa Barbara, e se la polvere non fosse stata scaricata per nove decisioni il giorno innanzi facilissimamente bruciava le altre quattro o cinque navi ch'erano ancorate vicino e con essa l'arsenale, e dei quartieri franchi di Pera e di Galata le case di pietra sarebbero andate in ruina e quelle di legno in fuoco ed in fumo. Con tutta la poca polvere che c'era lo scoppio fu talmente forte che parve terremoto; la città si scosse tutta ed i vetri delle finestre andarono in pezzi. Le vittime sono state poco su poco giù intorno a mille; sei soli camparono ma mezzi sfragellati ed in pericolo tutt'ora di vita. Per questi ed altri simili fatti di minor conto il governo è in apprensione; gli Ambasciatori dimandano grosse indennizzazioni per l'affare d'Aleppo e garanzie che per l'avvenire non abbia a succedere il simigliante ivi ed altrove. ${ }^{45}$

I can tell you that the score is always as good as it was the first evening, and that the theatre is crowded with spectators. Signora Penco, and Signora Lotti are the leading ladies, the deep bass Signor Mitrovich, while the tenor Signor Prudenza always receives great applause. Next Tuesday we will be on stage with Lucia, when Penco, Baggetti, Corsi, and Alessandrini will sing. On Saturday I will give you news. Now it is my purpose to tell you something about the presentation of my Hymn to the Great Sultan. Unfortunately, here serious events happened, which have upset the Court, diplomacy, and the current ministry. There has been a bloody revolution in Aleppo, and also I suppose in the surrounding areas, where they have cut a lot of the free population to pieces, looted the houses and burned the neighbourhood where they lived. At

Mariani's letter, Constantinople 9 November 1850, Corrispondenza, MS. PIV2_01b-046. 

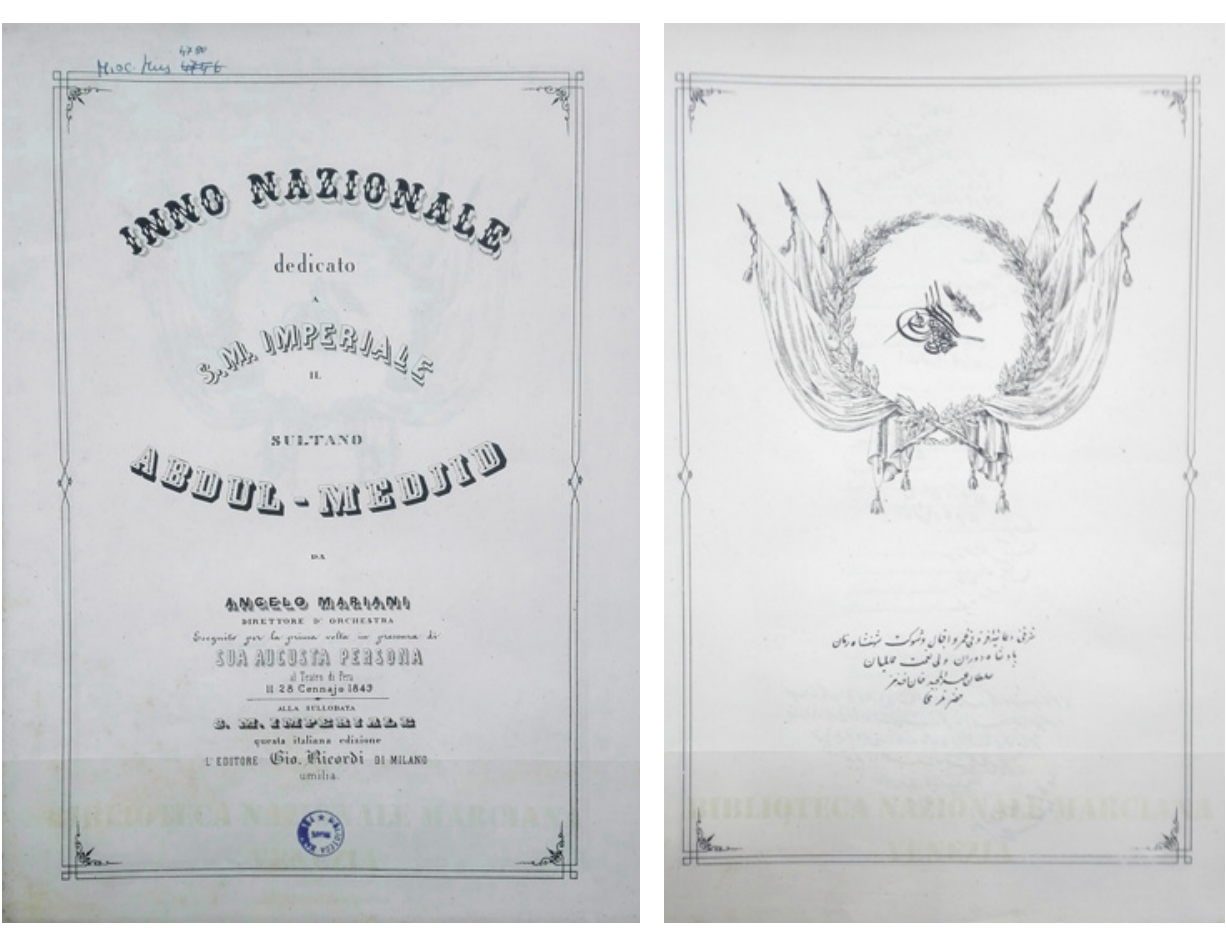

Figure 5a-c. Angelo Mariani, Inno Nazionale dedicato a S.M. Imperatore il Sultano AbdulMedjid. Eseguito per la prima vota in presenza di Sua Augusta Persona al Teatro di Pera il 28 gennaio 1849, 1850. Frontispiece, I-II. $\mathrm{I}-\mathrm{Vnm}$, misc. mus 4780

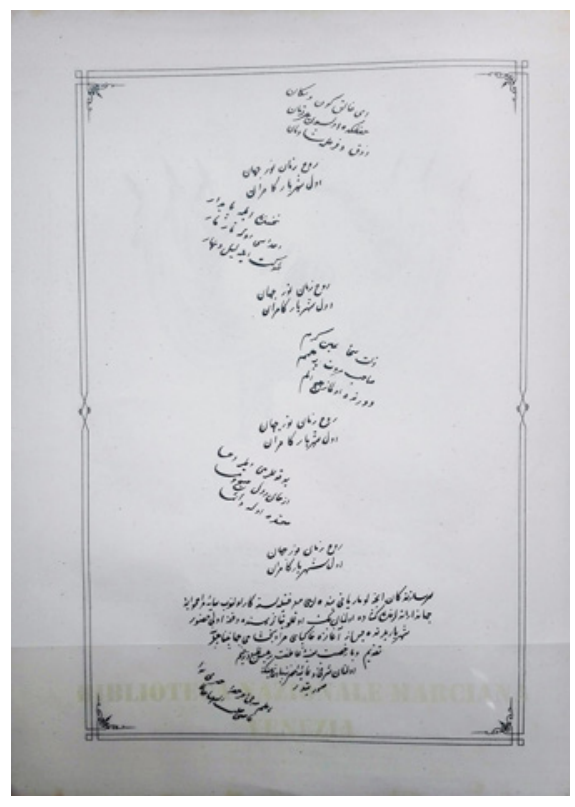




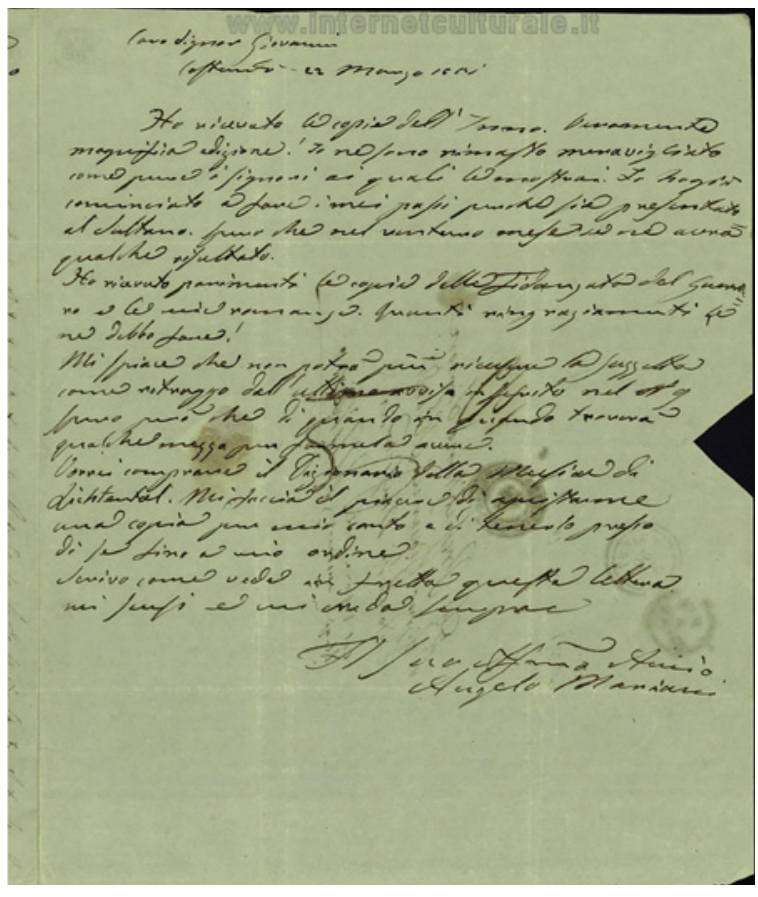

Figure 6. Angelo Mariani, Letter of 22 March 1851.

Milano, Archivio storico Ricordi, Fondo Corrispondenza, I-Mr MS. PIV2_01b-049.

the same time the flagship was blown up here, on which the Sultan was due to go in another half an hour. It was the largest wooden ship in the Turkish navy, three and a half decks with a hundred and sixty cannon. With nobody knowing how, the arsenal caught fire, and if it had not been decided to discharge the powder the day before, there could easily have burned the other four or five ships that were anchored near it and with it the arsenal, and the stone houses of the Frankish neighbourhoods of Pera and Galata would have gone to ruin and all those in wood would have gone up in fire and smoke. With all the little powder that there was, the blast was so strong that it felt like an earthquake; the city shook all over and the window panes shattered. The victims were more or less around a thousand; only six of them were still alive, but they were badly injured and in danger of their lives. With these and other similar minor events, the government is apprehensive; the Ambassadors demand large indemnities for the Aleppo affair and guarantees that for the future a similar thing will not happen here or elsewhere. (Transl. by the Author) 


\section{Constantinopolitan Developments in Other Italian Composers}

I can just point out here two other Italian composers in Constantinople about whom Aracı (2007, 277; 2010) Spinetti (2010; XVII, XXVI) and Baydar $(2010 ; 288-92)$ had recently discussed: the cello and double bass player and composer Callisto Guatelli (1820-1900) from Parma who during his long stay of sixty years in Constantinople working at Naum Theatre as player and 'maestro concertatore'. In 1856 he achieved the role of Head of Imperial Music succeeding Giuseppe Donizetti. Guatelli composed a collection of melodies entitled Arie nazionali e Canti popolari antichi e moderni. Similarly, the renowned Piedmontese composer Luigi Arditi (1822-1903), engaged as director for the 1856-57 opera's season at Naum Theatre, composed an Inno turco performed in 1856 in praise of Sultan Abdülmecid and later sung again during the sultan's Abdülaziz (1830-1876) visit to London on 16 July 1867 by an English choir of one thousand six hundred singers. ${ }^{46}$

Finally I have to distinguish from the previous the case of Bartolomeo Pisani (Constantinople 1829-post 1895) because he was Levantine not Italian as generally indicated in the scholars' studies. ${ }^{47}$ The almost unknown history of his own life placed him in a different and still unclear position. He was born in Constantinople in 1829 by Federico Maria Pisani and Thérèse Alléon, ${ }^{48}$ the descendant of a family of Italian origin long time resident in Constantinople and well-established among the European aristocracy: Pisanis, in fact, held for several generations the primacy of the prestigious position of dragoman of the British Legation. As a way to show his desire to re-appropriate his own culture, Bartolomeo Pisani completed his studies in Naples with Saverio Mercadante around the years 1850s, later composed operas for some important Italian theatres: Ladislao re di Napoli dedicated to the sultan Abdül Azız Khan (Naum Theatre, Constatinople, 1863; Teatro Pagliano, Florence, 1863), Rebecca with libretto of Francesco Maria Piave (Teatro alla Scala, Milan, 1865) and La Gitana (Teatro La Fenice, Venice, 1876). Unfortunately at the present all the musical scores of these operas seems lost, whereas some other autograph scores survive, for instance, the

46 The first recordings of this hymn of Arditi are available in İstanbul'dan Londra'ya CD 349 (Kalan) conducted by Emre Arac1; Arditi composed also an Oriental Cantata in praise of Sultan Abdulaziz Khan and performed at Crystal Palace. For further details of Arditi's stay in Constantinople, see Arditi 1896, 68-70, 325, 327.

47 See for instance Spinetti 2010, XXVI; Aracı 2006, 219.

48 Regarding the dates of birth and death of the composer, at the present state of research we refer to the information based on the genealogical research of the Levantini by Marie Anne Marandet. "Bartolomeo Pisani". Geneanet [online], https://gw.geneanet.org/marmar a2?lang=en\&n=pisani $\&$ oc $=0 \& p=$ bartolomeo $(2018-05-15)$, in contrast to what is indicated by Ambivieri (1998) according to whom Bartolomeo Pisani was born in 1811 and not in 1829. 
collection entitled Composition inedites pour piano et chants in Conservatorio "Luca Marenzio" of Brescia. ${ }^{49}$ Pisani maintained with Mercadante a sincere relationship of esteem and friendship over the following years: his education with the Neapolitan master was an important stage in his development and was reported in his unpublished correspondence in French with his friend Francesco Florimo, from 1852 to 1863, who at that time was the director at the Conservatory of San Pietro a Majella in Naples. ${ }^{\mathbf{5 0}}$ From these letters we learn some new biographical data, for instance that he travelled a lot and married an English wife, Margaret Turner.

On the same lines as Donizetti, Mariani and Arditi he also composed an Inno turco written in Turkish with Latin letters and dedicated it to Sultan Abdülmecid. At the end of the music score manuscript, we can read this hymn was composed in Constantinople in 1868. In a letter, probably of the same year of 1868 (incompletely dated 29 May) he enthusiastically recounts its performance:

J’ai fait exécuter un Hymne en turc chanté par toute la compagnie. Le copie joliment [écrite] a été présenté au Sultan par l'ambassador de France recommandant l'auteur que bien le Sultan a laissé en partant 25 mille $€$ à l'impresa. Et bien à moi. ${ }^{51}$

I had a Hymn performed and sung in Turkish by the whole company. The finely-written copy had been presented to the Sultan by the French ambassador informing the author that willingly the Sultan had left twenty-five thousand lira to the company. And so, well, to me. (Transl. by the Author)

Pisani, just as Donizetti formerly was, was in charge with the role of conductor to the Imperial Theatre. In his unedited letter of 10 December 1859, he wrote:

49 I-BRc, Pasin 235a-260a. As indicated in a note by author this collection was gifted to the friend Francesco Pasini in date Constantinople 12 May 1895 and include a lot of musics composed between the years 1867 and 1895. These details make more difficult determinate his biography because they are in contrast to Marandet see n. 40 and Ambivieri (1998). A messa a quattro voci e grande orchestra dedicated to Mercandate is preserved in Napoli, I-Nc, 10.7.11. Other sacred and secular of his musical pieces are scattered all around Italy: Trieste, Milan, Livorno, Turin, Rome and Naples. Araci refers also a march entitled Une Larme sur la tombe du Sultan Abdul-Mejid preserved in Paris, F-BnF, Vm 12, 23190 (Aracı 2006, 220). The librettos of his operas are preserved in Bologna, Parma, Vicenza, Venice, Florence and Naples. See also Araci 2010, 304.

50 I recently founded these letters in the Library of the Conservatory San Pietro a Majella of Naples and an annotated edition of this correspondence will be available with my $\mathrm{PhD}$ dissertation.

51 The unedited letter's manuscript is preserved at the Library of the Conservatory S. Pietro a Majella of Naples. Rari lettere MS. 19.2T XII. 8.13. 
Mon cher Florimo, mille remercimens de votre bonne et chère lettre dont M. Oliva était porteur. J'ai été enchanté de faire sa connaissance, c'est un excellent garçon. Et vous pouvez être sûr que je ferai tout ce que je puis pour lui être utile. Quoique il n'a pas besoin de moi il se trouve déjà trop bien recommandé. Nous avons beaucoup conté de Naples et de vous cela va sans dire. Il m’a rafraîchi mes souvenirs mais pas mon amitié pour vous ne la calculé pas par mes lettres.

Souvenez-vous des bontés que vous ami aves pour moi et dites-moi si je puis jamais cesser de vous aimer. J'ai reçu une lettre de Mme Diran. Elle se porte à merveille et chante toujours. Je veux bien la voir. J'ai été nommé chef d'orchestra du theatre Impérial. J'ai un bijoux du theatre petit mais le plus riche et le plus joli qu'un puisse voir. J'ai un orchestre de 45 personnes tous turcs. Des chœrs et des chanteurs turcs - tous mes élevés. Je fais exécuter des scènes des dues des potpourri d'opéra. Venez et vous entendrez. J'espère que vous mettrez en exécution votre ancien projet. Conservez la joie que j'aurai de vous revoir. ${ }^{\mathbf{2}}$

My dear Florimo, a thousand thanks for your kind and dear letter of which Mr. Oliva was the bearer. I was delighted to make his acquaintance, for he is an excellent garson. And you can be sure that I will do everything I can to help him. Although he does not need me as he is already too well recommended. We have said a lot about Naples and about you so there is no need to say more. He refreshed my memories but not my friendship for you, do not calculate it by my letters. Remember the kindness you have for me and tell me if I can ever stop loving you. I received a letter from Mrs. Diran. She is doing well and she continues to sing. I want to see her. I was appointed conductor of the Imperial Theatre. I have a little jewel of a theatre and the richest and most beautiful one can see. I have an orchestra of forty-five people, all Turkish. Turkish are both the choirs and the singers - all my students. I have had performed some scenes, some duets, potpourris and operas. Come and you will hear. I hope you implement your old project. Think of the joy that I will have on seeing you again. (Transl. by the Author)

As the case of Pisani demonstrates, the well-established Italian-Levantine community of Constantinople had assimilated Donizetti's lesson and participated in the metissage process producing composers, musician's exchanges, operatic performances and literary activities closely connected with opera, (as the several poems and translations of poetry written by Achille Tondi testify). In the letters quoted Pisani reports that the orchestra conducted by him was assembled entirely of Turks and his

52 I-Nc, Lettere a Florimo. Rari lettere 19. 2T. 
relationship with Adelaide Diran, an Armenian singer and composer, already well-known and appreciated by Angelo Mariani. This development of operatic culture was attested moreover by the increasing interest in the musical life in Constantinople addressed by Italian revues such as $L a$ Gazzetta Musicale di Milano, ${ }^{53}$ La Fama, Il Pirata, L'Italia Musicale ${ }^{54}$ and it is confirmed by the constitution of societies such as Società Musicale Italiana, Ausania, Unione Drammatica di Costantinopoli, Società Operaia di Mutuo Soccorso, Armonia and Teutonia. ${ }^{55}$ As a consequence, in those years Constantinople became an important centre for opera culture thanks to which a lot of Italian musical and theatrical terms came into use in Turkish, maintaining their original pronunciation (nota, solo, musica, tempo, canto, pagliaccio, prova, compagnia, impresario, etc). (Aksoy 2007, 70). In the years in which Pisani published his piece for voices and piano entitled Pace, the Armenian Ottoman composer, Dikran Çuhacıyan (Constantinople 1837-1889) with whom Pisani was in contact, produced the first Turkish opera entitled Arif Ağa'nin Hilesi 'The Trick of Arif' in 1874 and Leblebici Horhor Ağa 'Good old Horhor, the chickpea vendor' staged in $1875 .^{56}$

53 A revue imported from Italy whose circulation in Constantinople was possible mostly thanks to Mariani's great commitment to Istanbul's musical life and his advantageous friendship with the Milanese publisher Giovanni Ricordi.

54 The circulation in Constantinople of La Gazzetta Musicale di Milano, published by Ricordi and imported from Italy was possible mostly thanks to Mariani's great commitment to the Ottoman capital's musical life. Also the French and English presses were very interested in opera in Constantinople see for example Le Journal de Constantinople, The Musical World etc. and of course Turkish as Tekvim-i Vekayi and even Armeno-Turkish as Ceride-i şarkıye, Cihan see Cankara 2015, 6-9.

55 See Suner 2013, Pannuti 2008, 5-8.

56 Dikran Çuhaciyan was the son of the clockmaker of the Sultan and had his first musical education in Constantinople, from 1860 to 1864 he studied at Conservatory "Giuseppe Verdi" in Milan (during the same period of the Armenian impresario-composer Serafin Menasse). Arriving back in Constantinople he worked with Italian, Turkish and Ottoman Armenian musicians and theatre directors, composing several operas and operettas in Ottoman Turkish, French, Armenian and Italian. He is also considered the founder of the Armenian operatic tradition started with his Arshak II. See Mestyan 2017, 290. 


\section{First Conclusions and New Perspectives of Research: the Sacred Metastasian Dramas Translated by Hovannes Yeremian}

It seems to me widely demonstrated that the Italian opera in Constantinople presents some strongly original features: it is deeply settled into a multicultural context and becomes itself a multicultural factor whose characters are still far from being studied and defined in their breadth and depth despite the recent studies by Spinetti and Aracı. By the study of his Turkish lyrics, the portrait of Donizetti emerges with a more actively participatory ideological position in relation to the Tanzimat and with interesting specific reports on the history of the Turkish language; while the image of Mariani is proposed, through the study of his autobiographical diary of Constantinople and the letters with Ricordi, as that of a precious witness not only of the important developments of the artistic quality of the opera stagings, but also weaving together the Ottoman society and the circles of international diplomacy; the career of the Levantine Pisani, that we have met with new data, prove furthermore how Italian opera constitutes a meeting point between the people of Constantinople. Having said this, and having established the material documentary bases for future investigations, I would like to give my essay an open conclusion on a new perspective of research.

The last scenario of operatic culture influences in Constantinople I would like to discuss here present an even deeper link with the secular phenomena of cross-cultural encounter which was played out by the Christian Armenian community which had lived in Constantinople since the fifteenth century. ${ }^{57}$ In the early nineteenth century those phenomena manifested themselves in contradictory forms and often resulted in an open crisis within the multiethnic and social body of the great metropolis. What I have called 'scenario' opened in 1831, three years after the arrival of Donizetti in Constantinople, but was actually rediscovered in the twentieth century by the renowned Austrian Turkologist Andreas Tietze and to be exact starting with the essay published in Italy in 1979. As is known, Tietze endured exile under Nazism and this was precisely the reason that led him to Istanbul where he enjoyed political asylum which he always remembered with great gratitude. He was particularly attentive, in his work as a wide-ranging

57 Armenians' role during the nineteenth century went beyond commercial and producermanagerial activities and involved scientific and artistic culture as well. It is worth remembering the name of Séraphin Minasyan (1837-1888), a composer and a theatre producer able to compete with Naum's monopolistic activity. Minasyan was a well-known family name, as many of their members served in the Ottoman administration as translators or diplomats. See Mestyan 2011, 162-89. Sivazliyan (1986) claims that from the half of the nineteenth century the Armenian community of Constantinople became an economical, political and cultural essential centre for all Western Armenians. 
scholar, to the culture of minorities present in Constantinople, the so-called millet. Tietze also collaborated with Armenian scholars on the question of that misunderstood literature of the Armenians speaking Turkish who used to write in it in Armenian letters. ${ }^{58}$ In 1979 Tietze pointed out and with great refinement analysed the edition of four oratorios by Metastasio (that is to say, as a matter of fact, operas on a sacred subject) printed in Venice at the typography of the Armenian monastery of the Mekhitarist fathers of San Lazzaro and entitled Metastazyo Sairin Teliflerinden Bir Kaç Ruhani Kasideler Tercümeleridir (Some sacred musical drama from the repertoire of the poet Metastasio) translated into the common Turkish language written in Armenian characters; La morte d'Abel, translated into Turkish, Abelin ölümü (The Death of Abel); Isacco figura del Rendentore which in Turkish is rendered as Isahak efendimiz Yisusun Örneyi (Isaac Figure of Jesus our Lord); Giuseppe Riconosciuto, freely translated as Yovsep Qegesik, (or Joseph the Handsome); and La passione di Cristo translated as Yisus efendimizin siyaseti (The Passion of our Lord Jesus). The 1831 edition worked on by Tietze was presented anonymously and the scholar could only guess that it was intended for the audience of the Turkish-speaking Constantinopolitan Armenians. (Tietze 1979, 368).

Tietze was wrong to suppose that the author of the translation was a Mekhitarist monk, drawing this conviction from an allusive preface by the same translator, but he certainly noticed the great culture of this character, hoping for his identification in future studies. In this regard it is appropriate to let Tietze put it:

credo comunque si possa dire non soltanto che egli ha il merito di essere stato uno dei primi - o forse anche il primo - a tradurre in turco testi teatrali occidentali, libretti di opere musicali, ma che il suo lavoro è degno d'attenzione per la bellezza e la forza espressiva della lingua nonché per la magistrale tecnica traduzionale. (Tiezte 1979, 368)

I believe, however, that it can be said not only that he has the merit of having been one of the first - or perhaps the first - to translate into Turkish theatrical texts and librettos of musical works, and that his work is worthy of attention also for the beauty and the expressive force of the language as well as for the masterful translational technique. (Transl. by the Author)

Tietze then returned to these Metastasian subjects in 1994 to give a complete transliteration of the text of the first sacred drama, La morte d'Abel,

58 On the Armeno-Turkish literature see also Pamukciyan 2002, Strauss 2010, Stepanyan (s.d.), Cankara 2015, Vartanian 1991. 
from the original Turkish language in Armenian characters to the modern one in Latin characters (Tietze 1994). The scholar, however, was not aware of another edition of the same sacred dramas printed again, eight years later, in 1839, at the same Venetian Armenian Typography of San Lazzaro. ("Libri turchi" 1839, 376-377). This time, however, the name of the translator is explicitly mentioned: he is the Armenian baron Hovannes Yeremian who in the announcements of the new books printed in Italy which were included in the review Bibliografia Italiana is also defined as the first dragoman of the King of Denmark in Constantinople. So we easily come to know that he counts at least another couple of translations, among which there is the poem Yung Feylesofun Figanleri, yaxōd Yung'un Geceleri (Complaints of the Philosopher Young, or Young's Nights) by the English poet Edward Young, published again in Venice in 1836 at the Typography of the monastery of San Lazzaro. ${ }^{59}$

The reasons why this interesting character did not reveal himself in 1831 cannot have any definitive answer but we can observe that the first edition includes just those Metastasian oratorios whose stories, based on the Christian Bible, are mentioned in the Quran. We may think that this perhaps should have also facilitated the spread to, and acceptance by, a Muslim audience within the sultanate and perhaps in this regard there are signals in the translation: the names of the characters and the same name of God mainly cited as 'Allah'.

History tells us that the Armenian Christian millet had a period of relative peace and prosperity starting from 1831, and from 1839 its autonomy and freedom within the sultanate was further consolidated. ${ }^{60}$ Perhaps for this reason in 1839 Yeremian revealed himself and it is also noteworthy that in this edition he added a fifth drama, Betulia Liberata, whose fortune in the history of Western music of the eighteenth and nineteenth centuries was great. The same year Albrecht Krafft pioneer of Oriental Studies (1841), in his article in the review Jahrbücher der Literatur, presented Yeremian's translation with an extended comment including an Ottoman transliteration precisely from the lastly added oratorio. (To be precise Krafft transliterated the narration of the death of Holofernes that Judith tells of when she came back to the Judaic city). Betulia earned its author the epithet of a philosopher-poet and contains pages of extraordinary spiritual commitment to an absolutely non-iconic vision of the divine. However, it belongs to the tradition of the exegesis of the biblical character of Judith,

59 "Libri armeni e turchi" $(1837,231)$. The work consists of three books (volume 1 from first to ninth Night, volume 2 from tenth to seventeenth Night and volume 3 from fifteenth to twenty-fourth Night) for a total of 197 pages. Stepanyan 2005, 51.

60 In 1856 was promulgated a second edict called Islâhat Hatt-ı Hümâyûnu 'Imperial reform edict' which granted even more equality and government participation in the Ottoman office to the domestic leaders of each religious minorities. 
a female figure not mentioned in the Quran, an allegorical interpretation that reveals in itself the idea of nation. Did Yeremian perhaps want to take part in that wide rediscovery movement of the national identity that went under the name of the Armenian Renaissance, while proposing this within a vision of harmony between the peoples? These are the questions I am asking myself at present concerning an author about which almost nothing exists in any studies dedicated to him. ${ }^{61}$ Anyway, I am gradually acquiring very important data on Yeremian's involvement in the ecumenical debate between Armenian Christian communities and their relationships with Islam in those years.

In relation to the question of the musical use of the Metastasian translations by Yeremian I am following some trails. In this period the Armenian musicians called ashug were very productive. They sang in Turkish but their lyrics were written in Armenian characters and their very rich repertoire is today, sadly, still very little studied. They sang by blending the Turkish and Armenian singing traditions and some among them became accustomed to Western music. The ashug repertoire did not exclude the employment of the Christian biblical stories, carrying it with success even to the sultan's palace. ${ }^{62}$ Did Yeremian perhaps want to create a repertoire of texts that could be set to music but not necessarily as a written composition in the typical manners of Western music? Or did he rather want to make it available as an improvisational arrangement in the manner of the oral ashug poets' tradition? Were the ashugs wont to perform extrapolated scenes and arias of the sacred Metastasian dramas in the amiras $^{63}$ palaces and at the sultan's court? On this topic it is peculiar that one of the favorite pieces $^{64}$ of the sultan Abdul Aziz (1830-1876) was the famous Sird im sasani which recounts the scene in which Jesus washes the feet of his disciples

61 Some scholars such as Metin And (1974, 64-65) refers he could worked on these topic thanks to Tietze who provided to him the 1831's metastasian translation of these oratorios, and also other Turkish and Armenian scholars deal with it but without any extensive regard. See as instance Manok (2013).

62 For a recent detailed study on the ashugs see among the others Van Lint 2004.

63 The amiras were the representatives of the influential bourgeois families of the Armenian living in Constantinople. They enjoyed great prestige as bankers and as financial advisors, as well as holding important positions in the Ottoman government. As it is generally known the majority of them were adversed to the empire's renovation in order to maintain their privileges but at the same time they supported the economical and cultural development of Constantinople financing the building of several public schools, churches, and also an hospital and a typography. Some noteworthy names also linked with music development are: Düzyan, Bezciyan, Dadyan, and Balyan families. On this matter, see Agbabian Hubbard 2010, 289-92; Kerovpyan,Yllmaz 2010, 83-105. And for a more specific critical approach on amiras' role in this period see Barsoumian 1982, 171 and Sivazliyan 1986, 23; Dadyan (2012).

64 This piece used to be performed by the ashug Kemanı Sebuh. Hubbard (2010, 290) refer erroneously this piece was a hijaz which actually it indicates the fifth mode of the harmonic minor scale. About Kemanı Sebuh see also Bora (2010, 207-10). 
as a symbolic act of humility. ${ }^{65}$ Finally, Yeremian's aspiration seems to be that of developing a new, vulgar poetry suitable to secular spirituality and offering it through that sentimental dimension which Metastasio had impressed on the opera of his own century and the following one. I can only temporarily close this contribution by reporting Yeremian's preface to the collection of oratorios: a masterpiece of allusiveness and creativity that in its apparent naivety aims to have a profound effect on individual and collective consciences. ${ }^{66}$

\section{Ifadéi meram}

Dünyade derd deyi şikyayet etdiyimiz sıqıntıların dürlüsü` bi ġaraz mizan ıla vezn olunsa, işsizlik sıqıntısı ` kişiye pek küçük derd deyilikèn, niçe kimseler boş durmayı ' kèndilere rahatlıq, ve belki devlet sayarlar. Bazılar da’ ömrümuz pek uzun dur, vaqti biz her ne qadar telef etsek, eksileceyi yoq: zira punar başından biri biri ardı sıra gèliyor gibi, eylence, ve vaqut géçirmek şöhretleri ile kimi ġaybet, kimi qumar, kimi de ġayri bedxüya meşg்ul, o baha yetmez vaqti, o bir demi ile axretlerini yapacaq hazineyi ' bir çürük mal gibi israf etdiklerini taaccüb edecek şey, ve acınacaq haldır. A` zavallı, bu şimdiki vaqut ardından gèlecek vaqtin müjdecisi deyil dir: illa önünden qaçanın hisabını Yaradan senden istiyecek xaberini vermeye gèliyor. Gẻrçi kişiye défi ġam için bir eylence elzem odug̉u inkyar olunmaz: lakin bir eylence` ya tene, ya cana faidesi olmazsa daxi, zararı da olmamaq elzem olduǵu aşıkyar dır. Yoqsa ya ele, ya kèndiye zarar verib, qaĺbde nedamet braqacaq eylence` défi ġam olmaz, zámmi ġam olur mülahazalaríyla, zatin biri dünyaden el çekmiş iken, yine vaqtini boş géçirmemek için, kendiye eylence deyi şöhretyab Metastazyo şairin ruhaniye dair kitaplardan ixrac, ve Opera nami ile te'lif eylediyi işbu vezinsiz Qasideler 'örneksiz bir tertib ile etdiyi tercümeyi` bazı éhli vuquf gyorüb, tahsin edib basma olunmasını arzulediklerine binaen, oquyanlara daxi maqbul, ve günahsız bir eylence

65 The scene is an elaborate dagh-aria from votenlvat which is a ritual of the Armenian Church. See Agbabian Hubbard (2010, 290). Keşiş Oğlu was another Armenian ashug who used to perform for the sultan Abdülmecid see Van Lint 2004, 340-2.

66 I based my transliteration mainly on the pioneering and practically only studies on this topic provided by Tietze 1994 and Vartanian 1991, 9-21. Although these sources seem to me contradictory in the use of some conventions they allow me to proceed in a more accurate understanding of this subject. In the time between the writing of this article and its publication I have further investigated these topics finding answers to the proposed questions which presumably will be presented in a consequential essay or certainly with my Ph.D. thesis, in which will be available also a complete transliteration in Turkish characters of the second oratorio, İsahak efendimiz Yisusun Örneyi, 'Isacco Figura del Redentore' from Yeremian's translated book (1839) unite of the Italian translation of the Turkish text of this oratorio that I was able to translate thanks also to the generous guide of my Prof. Giampiero Bellingeri. 


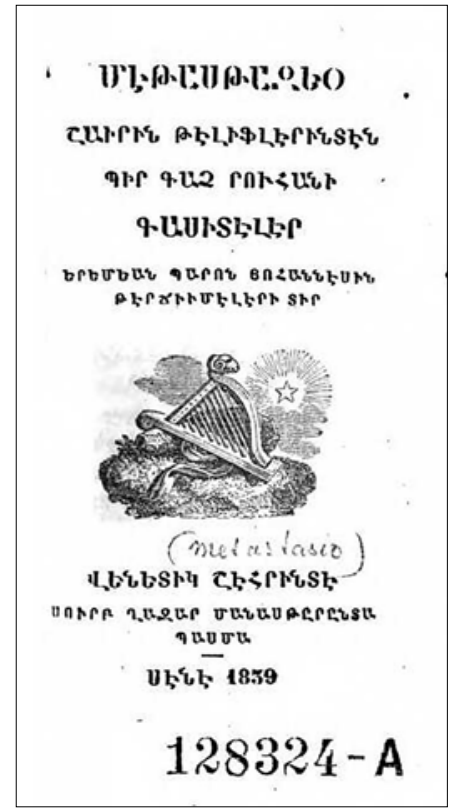

Figure 7. Pietro Metastasio, Metastazyo Şairin Teliflerinden Bir Kaç Ruhani Kasideler Tercümeleri dir. (Some sacred musical dramas from the repertoire of the poet Metastasio). Çev. Yohannes Yeremian, 1839. Frontispiece. Wien, ÖNB, 128324-A.

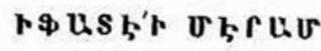

Figure 8. Pietro Metastasio, Metastazyo Şairin Teliflerinden Bir Kaç Ruhani Kasideler Tercümeleri dir. (Some sacred musical dramas from the repertoire of the poet Metastasio). Çev. Yohannes Yeremian, 1839. Preface. Wien, ÖNB, 128324-A.

tertib me'muli ile basma olunmuş dur. İnşa-Allah me'mulimiz boş olmaz. (Yeremian [Çev.], 1839)

\section{Expression of intent}

The variety of the sufferings we complain of, when weighed without prejudice, would make us observe that affliction due to idleness is not at all a small pain for a person, although many consider that remaining idle is a comfort and perhaps a fortune. In fact, our life is very long and as long as we waste time it will never be shortened. While standing one by one in line along the way to go and come back from a fountain, we note that some with fun and amusement disappear from society, those 
involved in gambling and those with other shady dealings. Now, it is astonishing and sorrowful to see the waste of time, almost like it was an out-of-date commodity, rather than taking advantage of every moment to treasure it. Ah wretched us, when our present time has gone the joyful messenger of the future will not come, but instead the announcement that the creator will want to present you with the account of what you missed in life.

Although it certainly cannot be denied that fun is necessary to dispel sadness, it is clear, however, that even if this is of no use, neither for the body nor for the spirit, it also likewise must not cause harm. Otherwise, harming other people and themselves, that fun which will have left remorse in the heart, will no longer be able to ward off affliction and make it heavier. On the contrary, a person who withdraws from the world and spends time for his own enjoyment draws out the authentic word from the sacred books of the renowned poet Metastasio. Some experts have noted this translation denotes an original pattern of Qasides [odi], without a metre, collected under the name of 'opera'. Proceed with people's desire by publishing a printed edition in the hope that it can be innocent fun and it will be also welcomed by the readers. If God wants all this, he will not disappoint our expectations. (Transl. by the Author)

\section{Bibliography}

Agbabian Hubbard, Lucina (2010). "The Musical World of Armenian in Constantinople”. Hovannesian, Payaslian (ed.), Armenian Constantinople. Costa mesa (CA): Mazda Publishers, 287-308.

Aksoy, Bülent (2010). "Music Relationships between Italy and Turkey". Spinetti, Federico (a cura di), Giuseppe Donizetti Pashà Traiettorie Musicali e Storiche tra Italia e Turchia = Atti del convegno internazionale, Giuseppe Donizetti Pascià: una vita Levantina. Traiettorie musicali e storiche tra Bergamo e Istanbul (Bergamo, 4 Dicembre 2007). Ranica (BG): Maggioni Lino, 61-77.

Ambivieri, Corrado (1998). Operisti minori italiani. Roma: Gremese Editore. And, Metin (2004). La scena Italiana in Turchia, La Turchia sulla scena Italiana. Ankara: Italian Culture Institute.

And, Metin (1972). Tanzimat ve istibat döneminde türk tiyatrosu (18391908). Ankara: Türkiye iş bankası kültür yayınları.

Aracı, Emre (2007). "Da Donizetti a Guatelli. Musicisti alla corte ottomana”. De Gasperis, Attilio; Ferazza, Roberta (a cura di), Gli italiani di Istanbul. Figure comunità $e$ istituzioni dalle riforme alla repubblica 1839-1923. Torino: Fondazione Giovanni Agnelli. 273-280. 
Aracı, Emre (2006). Donizetti Paşa. Osmanlı Sarayının Italyan Maestrosu. Istanbul: Yapı Kredi Yayınları.

Aracı, Emre (2010). Naum Tiyatrosu. 19 Yüyıl İstanbulu’nun İtalyan Operası. Istanbul: Yapı Kredi Yayınları.

Arditi, Luigi (1896). My Reminiscences. London: Skeffington and son.

Barsoumian, Hagop (1982). "The Dual Role of the Armenian Amira Class within the Ottoman Government and the Armenian Millet (1750-1850)". Braude, Benjamin; Lewis, Bernard (eds.), Christian and Jewish in the Ottoman Empire. The Function of the Plural Society, vol. I. New York: Holmes and Meier Publishers, 171-84.

Baydar, Evren Kutlay (2010). “Osmanlıda görevli iki italyan müzisyen: Giuseppe Donizetti ve Callisto Guatelli" [online]. Zeitschrift für die Welt der Türken, 2(1), 283-93. URL http://http://dieweltdertuerken.org/ index.php/ZfWT/article/viewFile/88/kutlay_baydar.

Behar, Cem (2013). Ali Ufki ve mezmurlar. Istanbul: Pan Yayıncılık.

Bombaci, Alessio (1948). Una lettera turca in caratteri latini del dragomanno ottomano Ibrahim al veneziano Michele Membre (1567). Krakow: Nakladem Polskiego Towarzystwa Orientalistycznego.

Bora, Emine (Hazırlayan) (2010). Klasik Osmanlı Müziğinde ve Emreni Bestekarlar. İstanbul: Surp Pırgıç Ermeni Hastanesi Vakfı Kültür Yayınları.

Calosso, Giovanni Timoteo (1857). Mémoires d'un vieux soldat. Torino: Gianini et Fiore; Nice: imprimerie société typographique.

Cankara, Murat (2015). "Rethinking Ottoman Cross-Cultural Encounters: Turks and the Armenian Alphabet" [online]. Middle Eastern Studies, 51(1), 1-16. DOI 10.1080/00263206.2014.951038.

“Cose straniere” (1885). La civiltà cattolica, 9(12).

Costanza, Maurizio (2010). La Mezzaluna sul filo - La riforma ottomana di Mahmûd II. Venezia: Marcianum Press.

Dadyan, Saro (2017). “Gaspare Fossati a Beyoğlu. Costruire la vita sociale del quartiere attraverso l'architettura". Monge, Claudio; Pedone, Silvia (a cura di), Domenicani a Costantinopoli prima e dopo l'impero ottomano. Storie, immagini e documenti d'archivio. Firenze: Edizione Nerbini.

Dadyan, Saro (2012). “Osmanlı ermenilerinin tarihindeki en büyük filântrop Kazaz Artin Amira Bezciyan”. Toplumsal Tarihi, 225.

Da Mosto, Andrea (1960). I dogi di Venezia nella vita pubblica e privata. Milano: A. Martello.

Da Smirne, Angelico (1955). Nuovo dizionario turco-italiano. Reggio Emilia: Libreria editrice "Frate Francesco".

“Della musica nella Turchia” (1852). Gazzetta Musicale di Milano. Milano: Ricordi, 140-1.

De Leone, Enrico (1967). L'impero ottomano nel primo periodo delle riforme (tanzìmāt) secondo fonti italiane. Milano: Dott. A. Giuffrè.

De Zorzi, Giovanni (2010). Musiche di Turchia. Tradizioni e Transiti fra Oriente e Occidente. Con un saggio di Kudsi Erguner. Milano: Ricordi. 
Donà, Giovanni Battista (1688). Della letteratura de' Turchi. Osseruationi fatte da Gio. Battista Donado senator veneto, fù bailo in Costantinopoli. Venetia: per Andrea Poletti. all'insegna dell'Italia, à San Marco.

Donizetti, Giuseppe (1846). Inno di S.A.I. il Sultano Abdul Medgid. Costantinopoli.

Donizetti, Giuseppe (1846). Inno di S.A.I. Validé Sultana. Costantinopoli. Donizetti, Giuseppe (1854). Silistria. Inno. Parole di A. Tondi. Musica del Cav. ${ }^{\text {re }}$ Donizetti. Costantinopoli. Luglio 1854. Costantinopoli.

Feldman, Walter (1996). Music of the Ottoman Court: makam, Composition and the Early Ottoman Instrumental Repertoire. Berlin: VWB.

Fornoni, Federico (2010). "Le lettere di Giuseppe Donizetti nell'archivio storico della Fondazione Donizetti". Spinetti, Federico (a cura di), Giuseppe Donizetti Pascià. Traiettorie Musicali e Storiche tra Italia e Turchia = Atti del convegno internazionale Giuseppe Donizetti Pascià: una vita Levantina. Traiettorie musicali e storiche tra Bergamo e Istanbul (Bergamo 4 Dicembre 2007). Ranica: Maggioni Lino Srl. 127-174.

Gabrieli, Francesco (1966). L'Islam nella storia. Bari: Dedalo. 139-42.

Kerovpyan, Aram; Yılmaz, Altuğ (2010). Klasik Osmanli Müziği ve Ermeniler. İstanbul: Surp Pırgıç Ermeni Hastanesi Vakfı Kültür Yayınları. Bgst yayınları

Gallotta, Andrea (1990). "Le caratteristiche fonetiche della Grammatica della lingua turca di Giovambattista Montalbano". Annali dell'Università degli Studi di Napoli "L'Orientale", 253-68.

Krafft, Albrecht (1841). "Türkische Werke aus der Druckeren der Mechitaristen auf S. Lazzaro bei Venedig”. Jahrbücher der Literatur, 96, 13-31.

Lacchia, Tito (1943). I Fossati architetti del sultano di Turchia. Roma: Edizione del Giornale di politica e di letteratura.

Lacchia, Tito (1939). "I mosaici di S. Sofia e l'opera dei fratelli Fossati”. Riv. stor. Ticinese, 5, 3-7.

Lamartine de, Alphonse (1841). Voyage en Orient (1832-1833). Paris: Librerie De Charles Gosseline.

"Libri armeni e turchi" (1837). Bibliografia italiana, ossia elenco generale delle opere d'ogni specie e d'ogni lingua stampate in Italia e delle italiane pubblicate all'estero, vol. 3. Milano: Ant. Fort. Stella e Figli, 231.

"Libri turchi" (1839). Bibliografia italiana, ossia elenco generale delle opere d'ogni lingua stampate in Italia e delle italiane stampate all'estero, vol. 5. Milano: Vedova di A.F. Stella e Giacomo Figlio, 376-7.

Manok, Yerevant Baret (2013). Doğu ile Batı arasında San Lazzaro Sahnesi. Ermeni Mıkhitarist Manastırı ve ilk Tyatro oyunları. Istanbul: Bgst yayınları.

Mantovani, Tancredi (1921). Angelo Mariani. Roma: Ausonia.

Mariani, Angelo (1849). Inno Nazionale dedicato a S.M. Imperatore il Sultano Abdul-Medjid. Eseguito per la prima vota in presenza di Sua 
Augusta Persona al Teatro di Pera il 28 gennaio 1849. Milano: Giovanni Ricordi.

Marrone, Gianfranco (2001). Corpi sociali. Processi comunicativi e semiotica del testo. Torino: G. Enaudi.

Mestyan, Adam (2011). "A garden with mellow fruits of refinement” [ETD. Collection]. Music Theaters and Cultural Politics in Cairo and Istanbul, 1867-1892. Budapest: CEU editore.

Mestyan, Adam (2014). "Sound, Military Music, and Opera in Egypt During the Rule of Mehmet Ali Pasha r. (1805-1848)" Michael Hüttler; Hans Ernst Weidinger (eds.), Ottoman Empire and European Theatre, Vol. II, The Time of Joseph Haydn: from Sultan Mahmud I to Mahmud II (r. 730-1839) = Proceeding of the Don Juan Archive Symposium (Wien, 24 April 2009). Wien: Hollitzer Wissenschaftsverlag.

Metastasio, Pietro (1839). Metastazyo Şairin Teliflerinden Bir Kaç Rühani Kasideler Tercümeleri dir. Çeviren Yohannes, Yeremian. Venedik: San Lazzaro Yayınevi.

Metastasio, Pietro (1996). Oratori Sacri. A cura di S. Stroppa. Venezia: Marsilio Editori.

Nerval, Gérard De (1997). Viaggio in Oriente. A cura di Bruno Nacci. Torino: Enaudi.

Palumbo Fossati Casa, Isabella (2006). "La straordinaria avventura in Turchia dei fratelli Fossati, architetti e pittori". Concina, Ennio (a cura di), Venezia e Istanbul, incontri, confronti e scambi. Udine: Forum Editore, 285-92.

Pamukciyan, Kevork (2002). Ermeni Harfli Türkçe Metinler. Istanbul: Aras Yayıncılık.

Pedani, Maria Pia (2006). Breve storia dell'Impero ottomano. Roma: Aracne editrice.

Potito, Amedeo (1985). Angelo Mariani (Autobiografia e documenti) 18211873. Rimini: Bruno Ghigi Editore.

Ramon Bisogni, Vincenzo (2009). Angelo Mariani. Tra Verdi e la Stolz. Varese: Zecchini Editore.

Redhouse, James (2014). New Redhouse Turkish English Dictionary. V. Bahadır Alkım, Nazime Antel, Robert Avery, Janos Eckmann, Sofi Huri, Fahir Iz Mecdud Mensurolu and Andreas Tietze (eds). Istanbul: Redhouse Yayınevi.

Rocchi, Luciano (2013). “Gli italianismi nei testi turchi in trascrizione. Un'indagine storico-lessicografica” [online]. Zeitschrift für Romanische Philologie, 129, 4. Berlin/Boston: Walter de Gruyter GmbH.

Russi, Angelo (2009). “Due lettere inedite di Achille Tondi a Giulio Minervini conservate nella Biblioteca Apostolica Vaticana”. Archaeologiae. Research by Foreign Missions in Italy, 7(1-2), 53-123. 
Syvazliyan, Baykar (1986). Scambi culturali, economici, amministrativi tra gli armeni e l'impero ottomano nel XIX secolo. Venezia: Tipo-litografia armena dell'isola di San Lazzaro.

Stepanyan, Hasmik A. (2005). Bibliographie des livres et de la presse armeno-turque 1727-1968. İstanbul: Turkuaz Tayinları.

Stepanyan, Hasmik A. (n.p.). Turkish Literature in Armenian Letters and Armenian-turkish Literary Relations in the Ottoman Empire in the XIXth Century.

Strauss, Johann (2010). “Is Karamanli Literature Part of a 'Chirstian-Turkish (Turco-Chirstian) Literature'?”. Balta, Evangelia; Kappler Matthias (eds.), Crisis and Whispers in Karamanlidika Books. Proceedings of the First International Conference on Karamanlidika Studies (Nicosia, 11-13 September 2008). Wiesbaden: Harrassowitz Verlag, 154-200.

Suner, Suna (2013). " The Earliest Opera Performances in the Ottoman World and the Role of Diplomacy: A Remapping from the Fifteenth to the Twentieth Century". Michael Hüttler; Hans Ernst Weidinger (eds.), Ottoman Empire and European Theatre, vol. I, The Age of Mozart and Selim III (1756-1808) = Proceedings of the Don Juan Archive Symposium (Istanbul, 5-6 June 2008) Wien: Hollitzer Wissenschaftsverlag.

Tedesco, Anna (2008). “MARIANI, Angelo” [online]. Dizionario Biografico degli Italiani. http://www.treccani.it/enciclopedia/angelo-mariani_ \%28Dizionario-Biografico\%29/ (2018-30-04).

Tietz, Frederich (1838). Bunte skizzen aus Ost und Süd. Entworfen und gesammelt in Preussen, Russland, Türkei, Grichenland, auf den ionischen Inseln und Italien. Leipzig: J.U. Brodhause.

Tietze, Andreas (1994). “Kain und Abel (Die armeno türkische Übersetzung eines Oratorium von Metastasio)”. Rocznik orientalistyczny, 29(2), 190217.

Tietze, Andreas (1979). “Nuovi dati sui primordi dell'opera in Turchia”. Ferrara degli Uberti, Luigi (trad. di), Le relazioni tra l'Italia e la Turchia, 23(2-4), 363-9.

Toderini, Giambattista (1787). Letteratura turchesca. Venezia: Giacomo Storti.

Tondi, Achille (1850). “Carteggi Particolari”. Gazzetta Musicale di Milano. Milano: Giovanni Ricordi.

Toscani, Claudio (2010). “Mamma li turchi! Percorsi esotici nell’opera italiana di primo Ottocento". Spinetti, Federico (a cura di), Giuseppe Donizetti Pashà Traiettorie Musicali e Storiche tra Italia e Turchia. Atti del convegno internazionale, Giuseppe Donizetti Pascià: una vita Levantina. Traiettorie musicali e storiche tra Bergamo e Istanbul (Bergamo, 4 Dicembre 2007). Ranica (BG): Maggioni Lino, 79-99.

Trivulzio de Belgiojoso, Christine (1946). Souvenirs dans l'exil. Milano: Ist. Edit. italiano. It. Transl.: Ricordi nell'esilio. Ed. by Maria francesca Daivì. Pisa: Edizioni ETS, 2001. 
Turan, Namık Sinan; Komşuoğlu, Ayşegül (2007). "From Empire to the Republic: the Western music tradition and the perception of opera". International Journal of Turcologia, 2(3). Paris: Stapany Melek.

Türk, Emine (2007). "Il contributo degli esuli italiani". De Gasperis, Attilio; Ferazza, Roberta (a cura di), Gli italiani di Istanbul. Figure comunità e istituzioni dalle riforme alla repubblica 1839-1923. Torino: Fondazione Giovanni Agnelli, 287-90.

Vartanian, Hovsep (1991). Akabi hikayesi. Hazırlayan A. Tietze. Istanbul: Eren Yayıncilık.

Walker, Frank (1962). The Man Verdi. London: Dent and Sons. It. Transl.: L'uomo Verdi. Milano: Mursia, 1964.

Woodard, Kathryn (2011). "Music in the Ottoman Imperial Harem and the Life of Composer Leyla Saz (1850-1936)". International Alliance for Women in Music Journal, 10(1), 1-7.

Üngör, Etem Ruhi (1981). Türk Musikisi Güfteler Antolojisi. İstanbul: Eren Yayınları.

Yağmur, Ömer (2014). "Erken Dönem Türkçe Transkripsiyon Metinleri ve Bunların Dil Araştırmaları Açısından Önemi" [online]. Insan ve Toplum Bilimleri Dergisi, 4, 201-17. URL https://www. researchgate. net/publication/286192154.

Zavadini, Guido (1948). Donizetti. Vita Musiche. Epistolario. Bergamo: Istituto d'arti grafiche.

Zoppi, Umberto (1947). Angelo Mariani, Giuseppe Verdi e Teresa Stolz in un carteggio inedito. Milano: Garzanti.

Zürcher, Erik Jan (1994). Turkey: A modern History. New York: I.B. Tauris $\&$ Co Ltd. 